\title{
WYKORZYSTANIE PUBLIKACJI FRANCUSKICH PRZY REALIZACJI NAGROBKÓW NA CMENTARZACH WARSZAWY W LATACH 1840-1860. WZORNIK JOSEPHA MARTY'EGO
}

\begin{abstract}
Dzieło Josepha Marty'ego Les principaux monuments funéraires du Père-Lachaise, de Montmarte, du Mont-Parnasse et autres cimetières de Paris, to - obok publikacji Ferdinanda Quaglii Le Père Lachaise ou Recueil de dessins au trait et dans leurs justes proportions des principaux monuments de ce cimetière (I832) i Louisa Marii Normanda Monuments funéraires choisis dans les cimetières de Paris et des principales villes de France (I832) - kolejny przykład wydawnictwa wzornikowego pochodzącego z pierwszej połowy XIX w.; ukazało się ono w Paryżu w roku I839․ Selekcji zamieszczonych w tym zbiorze nagrobków dokonał nieznany z imienia architekt Rousseau. Każda z 86 planszy mieściła jeden obiekt opatrzony podziałką, któremu towarzyszył krótki opis autorstwa Marty’ego. Wykonawcą kolorowych litografii był Émile Lassalle (I8I3-I87I)². Wydawnictwo to, tak jak dwa wcześniejsze, trafiło do Warszawy na początku lat 40. XIX w. Na stołecznych cmentarzach w latach I840-I860 powstało trzynaście obiektów, które odwzorowują formę siedmiu nagrobków pochodzących $\mathrm{z}$ tej publikacji ${ }^{3}$.
\end{abstract}

\footnotetext{
* Dr Marta Wiraszka - wykładowca historii architektury w Instytucie Historii Sztuki UKSW w Warszawie. Zajmuje się zagadnieniami z historii urbanistyki i architektury XIX i pierwszej połowy XX w., w szczególności byłych kresów południowo-wschodnich Rzeczypospolitej oraz kaplic i mauzoleów budowanych na polskich cmentarzach wyznań chrześcijańskich. E-mail: mwiraszka@poczta.onet.pl.

1 Artykuł jest kontynuacją opracowania o podobnym tytule Wykorzystanie publikacji francuskich przy realizacji nagrobków na cmentarzach Warszawy w latach 1840-1860. Wzorniki Normanda i Quaglii, który ukazał się w październiku 2017 r. Druk części drugiej poświęconej wzornikowi Josepha Marty’ego, mimo iż napisany podobnie jak poprzedni w 2015 r., musiał poczekać na opublikowanie do momentu ukazania się części pierwszej. Zarys stanu badań i wprowadzenie do tematu zostało przedstawione we wcześniejszym artykule, w tym natomiast umieszczono wnioski końcowe odnoszące się do obu opracowań. Z tych względów do niniejszego artykułu zostały dołączone zestawienia obiektów, obejmujące zarówno przykłady zaczerpnięte z wzorników Ferdinanda Quaglii (1832) i Louisa Marie Normanda (1832), jak też z publikacji Josepha Marty’ego (1839). M. Wiraszka, Wykorzystanie publikacji francuskich przy realizacji nagrobków na cmentarzach Warszawy w latach 1840-1860. Wzorniki Normanda i Quaglia, „Artifex Novus”, 2017, nr 1, s. 44-59.

2 Zob. J. Marty, Les principaux monuments funéraires du Père-Lachaise, de Montmarte, du Mont-Parnasse et autres cimetières de Paris, Paris 1839.
}

3 Zob. Zestawienie Nagrobków warszawskich zaczerpniętych z wzornika Josepha Marty'ego (1839). 
Najwcześniejszym odnalezionym w Warszawie przykładem jest pomnik Franciszka Ziemieckiego (zm. 2 XII I843) na Cmentarzu Powązkowskim (kw. Io, rz. 4) ${ }^{4}$. Nagrobek, stojący nad mogiłą radcy skarbowego, ufundowali przyjaciele i koledzy zmarłego w pierwszą rocznicę śmierci (pośw. 2 XII I844) . Wykonany z piaskowca, w formie steli o bokach nieznacznie górą ku sobie nachylonych, został zwieńczony gzymsem cavetto z płaskorzeźbionym dyskiem solarnym oraz trójkątnym naczółkiem z krzyżem i parą akroteriów po bokach. W tympanonie znajduje się wyobrażenie uroborosa, węża połykającego własny ogon. Środek steli wypełnia prostokątna płycina z inskrypcją, którą flankuje para pochodni z płomieniem skierowanym do dołu. Cokół zdobią natomiast dwie amfory i gasnący kaganek oliwny umieszczony w prostokątnym zagłębieniu'.

Stela Ziemieckiego jest wiernym powtórzeniem pomnika Gabriella Marie Jeana Baptista Legouvè (I767-I8I2), który znajdował się niegdyś na paryskim cmentarzu Montmartre [il. I]. Nagrobek francuskiego poety, nawiązujący do tradycji egipsko-antycznej i wykorzystujący motywy o charakterze wanitatywnym, powstał zapewne wkrótce po jego śmierci ${ }^{7}$ Obecnie niezachowany. Został zniszczony w I888 r. podczas budowy wiaduktu, który przeciął cmentarz na pół w celu ułatwienia dojazdu na Wystawę Światową. Wygląd steli znany jest z odbitki litograficznej zamieszczonej we wzorniku Josepha Marty’ego oraz innych pomników nagrobnych, dla których stał się inspiracją. W grupie tej znajdują się kolejne nagrobki zachowane na Starych Powązkach. Są one własnością rodzin Witoszyńskich (kw. I5, rz. 6) i Krzemińskich (kw. 37, rz. 2) oraz małżonków Adamowskich (kw. I2, rz. 4) i Majewskich (kw. 7, rz. 5). Do tego zespołu należy również znajdujący się poza Warszawą pomnik Piotra Alkantarego Sumińskiego, który stoi na Cmentarzu Świętokrzyskim w Pułtusku (sektor BI, rz. D).

W odniesieniu do tych realizacji nie udało się precyzyjne ustalić czasu ich powstania. Przyjęto więc przybliżone datowanie - rok od śmierci osoby, dla której najpewniej został wystawiony. Zgodnie z tym założeniem, pierwszym chronologicznie nagrobkiem byłby pomnik, zmarłego 28 lutego I840 r. i pochowanego w Pułtusku, Piotra Alkantarego

\footnotetext{
4 FRANCISZEK ZIEMIECKI, urodzony 5 X 1786 r. w mieście Korzec na Wołyniu, był synem Floriana Ziemieckiego (zm. 14 V 1815 w Lublinie) i Marianny z Kniflów (zm. 21 III 1821 w Warszawie). Pracował w Warszawie w Wydziale Skarbowym Komisji Województwa Mazowieckiego jako generalny kontroler wypłat, potem jako komisarz; następnie został radcą rządowym guberni mazowieckiej. Żonaty z Marianną z d. Polakowską (ur. 1789, zm. 11 X 1848), rozwódką po Tomaszu Czyszkowskim, córką Wojciecha (zm. 9 VI 1820 w Warszawie) i Zuzanny z Rutkowskich (zm. ?), małżonków Polakowskich, którzy tak jak Ziemiecki przybyli do Warszawy z Korca na Wołyniu. Małżonkowie mieli trzy córki: Ludwikę Aleksandrę (późniejszą Józefową Gepner), Wiktorię i Franciszkę Teklę (późniejszą Pawłową Parol). Archiwum Państwowe m.st. Warszawy (dalej: APW), Akt matzeństwa Franciszka Ziemieckiego i Marianny z Polakowskich Czyszkowskiej, Warszawa ASC Cyrkuł III, 1822, nr 11; Archiwum Archidiecezjalne Warszawskie (dalej: AAW), Akt urodzenia Franciszki Tekli Ziemieckiej, par. św. Jana Chrzciciela w Warszawie, 1833, nr 85; APW, Akt zgonu Franciszka Ziemieckiego, par. Nawiedzenia NMP w Warszawie, 1843, nr 914; [Nekrolog Franciszka Ziemieckiego], „Kurier Warszawski”, 1843, nr 321, s. 1521, nr 322, s. 1529; APW, Akt zgonu Marianny Ziemieckiej, par. Nawiedzenia NMP w Warszawie, 1848, nr 1377; APW, Akt matżeństwa Franciszki Tekli Ziemieckiej i Pawła Parola, par. św. Jana Chrzciciela w Warszawie, 1852, nr 11; APW, Akt malzeństwa Ludwiki Aleksandry Ziemieckiej i Józefa Gepnera, par. św. Andrzeja w Warszawie, 1854, nr 203.

5 „Kurier Warszawski”, 1844, nr 324, s. 1533-1534.

6 Krótki opis pomnika Ziemieckiego z przytoczeniem inskrypcji nagrobnej opublikował Kazimierz Władysław Wóycicki. Zob. K.W. Wóycicki, Cmentarz Powazkowski pod Warszawa, t. 1, Warszawa 1855, s. 209 i przypis nr 1 tamże.
}

J. Marty, dz. cyt., s. 215-217 (litografia, s. 217). 

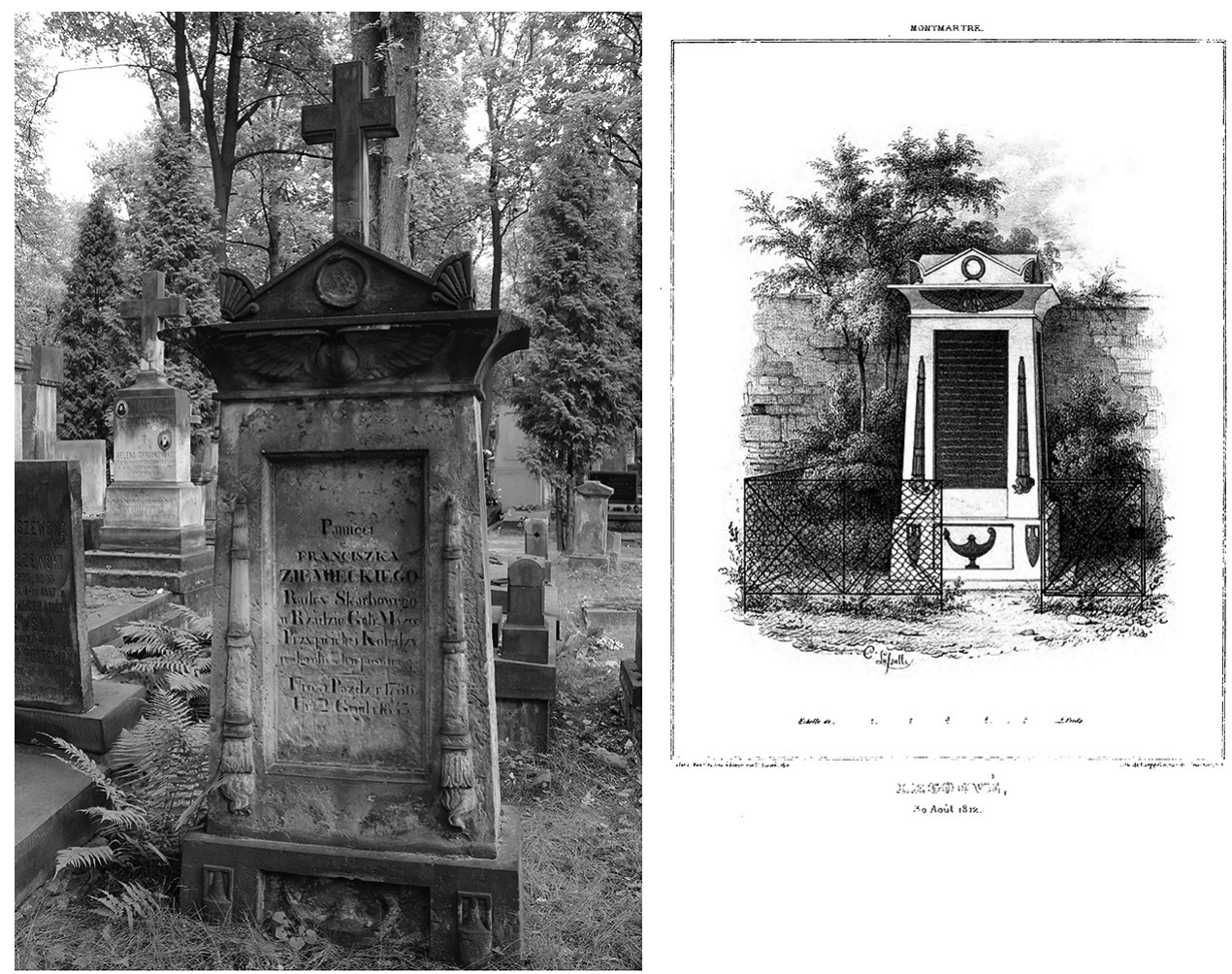

Il. I. Stela Franciszka Ziemieckiego na Starych Powazkach oraz litografia z wzornika Marty'ego. Fot. M. Wiraszka

Sumińskiego ${ }^{8}$. Gdyby udało się potwierdzić okres fundacji na lata I840-I84I, wówczas byłby to najwcześniejszy przykład wykorzystania na ziemiach polskich wzorów pochodzących z opracowania Marty'ego, który wyprzedzałby o trzy-cztery lata realizację steli Ziemieckiego w Warszawie. Ponieważ jednak brak jest udokumentowanych informacji na temat zmarłego, nie ma pewności, czy stela powstała zaraz po jego śmierci, czy nieco później. Pozostałe przykłady tej grupy, wstępujące na Powązkach, pojawiły się dopiero w drugiej połowie lat 40. XIX w. Najstarszy z nich stanął w miejscu pochówku Józefy Łucji z Witoszyńskich (zm. I9 VII I847), żony jubilera wyznania ewangelicko-augsburskiego Karola Winklera, która zmarła po szesnastomiesięcznej chorobie, osierociwszy męża i troje dzieci. Fundatorami pomnika byli mąż i rodzice zmarłej․ Rok później podobny nagrobek został ufundowany

8 T.M. Rudkowski, Cmentarz Świętokrzyski w Pultusku, w: 200 lat cmentarza Świętego Krzyża w Pultusku, red. R. Lolo, Z. Morawski, Pułtusk 2004, s. 52, 106 (fot. nagrobka).

9 JÓZEFA Łucja WINKLER z d. Witoszyńska, urodzona w Warszawie w 1817 r., była córką majstra szewskiego, Wincentego Witoszyńskiego (zm. 17 II 1862) i Katarzyny ze Zdroikowskich (zm. 4 X 1855). W 1834 r. poślubiła starszego o 18 lat Karola Winklera, wdowca po Józefie z Gronczewskich (zm. 1829). Małżonkowie mieli co najmniej pięcioro dzieci, z których tylko troje żyło w chwili śmierci ich matki. Józefa Winkler została pochowana na Cmentarzu Powązkowskim, w miejscu, gdzie później zostali pochowani jej rodzice. AAW, Akt matżeństwa Karola Winklera i Józefy Eucji Witoszyńskiej, par. św. Jana Chrzciciela w Warszawie, 1834, nr 148; AAW, Akt urodzenia Zuzanny Katarzyny Winkler, par. św. Jana Chrzciciela w Warszawie, 1835, nr 470; AAW, Akt urodzenia Wincenty 
przez Mariannę z Czyżewskich Krzemińską po śmierci męża Mateusza Krzemińskiego (zm. 2I XI I848), murarza i właściciela nieruchomości przy ul. Żabiej w Warszawie (nr hip. 956 C) ${ }^{10}$. Następny upamiętniał małżonków Adamowskich, zmarłego w roku I850 Bonawenturę - referenta w Biurze Rady Administracyjnej Królestwa Polskiego i rok później zmarłą Katarzynę z Kaczyńskich ${ }^{\text {II }}$ Ostatni dedykowany był Janowi Majewskiemu (zm. 6 III I867) i jego żonie Klarze z Chodurskich (zm. I6 II I844) ${ }^{\mathrm{I2}}$. Pomnik wzniesiono, sądząc z rozmieszczenia inskrypcji, dopiero po śmierci radcy stanu i byłego członka intendentury wojskowej - Jana Majewskiego ${ }^{\text {I3 }}$.

Stan zachowania obiektów, z wyjątkiem pomnika małżonków Majewskich, jest na ogół dobry. Omówione przykłady prezentują zróżnicowany poziom wykonania, który wyklucza możliwość realizacji przez tę samą osobę. Najsłabszy technicznie jest pomnik małżeństwa Adamskich. Dobry poziom rzemiosła kamieniarskiego demonstrują natomiast nagrobki

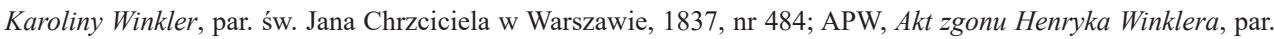
św. Andrzeja w Warszawie, 1839, nr 92; APW, Akt zgonu Józefa Winklera, par. św. Andrzeja w Warszawie, 1845, nr 100; AAW, Akt zgonu Józefy Eucji Winkler, par. św. Jana Chrzciciela w Warszawie, 1847, nr 390; [Nekrolog Józefy Łucji Winkler], „Kurier Warszawski”, 1847, nr 191, s. 919, nr 197, s. 947; [Nekrolog Katarzyny ze Zdroikowskich Witoszyńskiej], „Kurier Warszawski”, 1855, nr 263, s. 1335 oraz inskrypcja zamieszczona na pomniku nagrobnym.

10 MATEUSZ KRZEMIŃSKI był synem przybyłego do Warszawy z Wolnego Miasta Krakowa Łukasza Krzemińskiego (ur. ok. 1744 - zm. 27 X 1829 w Warszawie), z zawodu furmana, i Małgorzaty Wróblewskiej. Dwukrotnie żonaty, najpierw z Barbarą Katarzyną Wierzbicką (zm. 19 IX 1838; ślub: 21 VII 1816), potem z Marianną Czyżewską (ślub: 30 I 1845). APW, Akt matżeństwa Mateusza Krzemińskiego i Barbary Katarzyny Wierzbickiej, Warszawa ASC Cyrkuł VII, 1816, nr 125; AAW, Akt zgonu Łukasza Krzemińskiego, par. św. Aleksandra w Warszawie, 1829, nr 596; AAW, Akt matżeństwa Mateusza Krzemińskiego i Marianny Czyżewskiej, par. św. Aleksandra w Warszawie, 1845, nr 16; APW, Akt zgonu Mateusza Krzemińskiego, par. św. Andrzeja w Warszawie, 1848, nr 653; [Nekrolog Mateusza Krzemińskiego], „Kurier Warszawski”, 1848, nr 312, s. 1501, nr 321, s. 1541.

Nagrobek Krzemińskich został zmodernizowany na początku XX w., zapewne jeszcze przed śmiercią literata Stanisława Krzemińskiego (zm. 29 XI 1912), nieślubnego syna Mateusza i Marianny z Czyżewskich, ur. 16 grudnia 1839 r. w Ostrowie, w guberni łomżyńskiej. Wtedy płyta z inskrypcją jego ojca, macochy i trójki rodzeństwa została przeniesiona i wmurowana w tylną ścianę, a jej miejsce, na froncie pomnika zajęła tablica z czarnego, polerowanego granitu z portretem zmarłego wykonanym przez Czesława Makowskiego w 1905 r. APW, Akt zgonu Stanisława Krzemińskiego, par. Najświętszego Zbawiciela w Warszawie, 1912, nr 304; Z. Dębicki, Stanisław Krzemiński, „Kurier Warszawski”, 1912, nr 331 dod. por., s. 1-2; M. Dubrowska, A. Sołtan, Powazkowskie medaliony i plakiety portretowe, Warszawa 1992, s. 105.

11 BONAWENTURA Józef ADAMOWSKI urodził się w 1793 r. we wsi Zabłotów w Galicji austriackiej. Był synem Franciszka, obywatela, i Teresy z Rzepiańskich. Za służbę urzędniczą w Radzie Administracyjnej Królestwa Polskiego został uhonorowany Orderem św. Stanisława kl. III. Żonaty najpierw z Marianną Jagodzińską (zm. 28 IV 1832), następnie z Katarzyną Kaczyńską (zm. 9 XI 1851; ślub: 17 VI 1837), z którą został razem pochowany. APW, Akt zgonu Marianny Adamowskiej, par. św. Jana Chrzciciela w Warszawie, 1832, nr 289; APW, Akt matżeństwa Bonawentury Adamowskiego i Katarzyny Kaczyńskiej, par. św. Jana Chrzciciela w Warszawie, 1837, nr 103; APW, Akt zgonu Katarzyny Adamowskiej, par. św. Andrzeja w Warszawie, 1851, nr 578; [Nekrolog Bonawentury Adamowskiego], „Kurier Warszawski”, 1850, nr 287, s. 1527; [Nekrolog Katarzyny Adamowskiej], „Kurier Warszawski", 1851, nr 298, s. 1595.

12 JAN MAJEWSKI, urodzony w 1789 r. w Kurlandii, ale przez większą część życia zamieszkały w Warszawie, gdzie był urzędnikiem intendentury wojskowej, potem radcą kolegialnym. Odznaczony Orderami św. Włodzimierza kl. III oraz św. Anny i św. Stanisława. Żonaty z Klarą Chodurską, urodzoną w 1796 r. w mieście Romanów, niedaleko Żytomierza. APW, Akt zgonu Klary Majewskiej, par. św. Aleksandra w Warszawie, 1844, nr 85; APW, Akt zgonu Jana Majewskiego, par. św. Aleksandra w Warszawie, 1867, nr 93; [Nekrolog Jana Majewskiego], „Kurier Warszawski”, 1867, nr 55, s. 329.

13 Tekst inskrypcji umieszczony od frontu, w prostokątnej płycinie: Tu spoczywaja zwłoki ś.p. /JANA/ MAJEWSKIEGO/ [...]/ zmart 6 marca 1867/ po przeżyciu lat 78/ i [...] KLARY z CHODURSKICH/ MAJEWSKIEJ/ zm: d. 16 lutego $1844 \mathrm{r}$. Zachowała się też częściowo inskrypcja we wnęce cokołowej: ALEKSANDRA/ MAJEWSKA ZM. D. 15 LUTEGO 1898/ W WIEKU LAT [...]. 

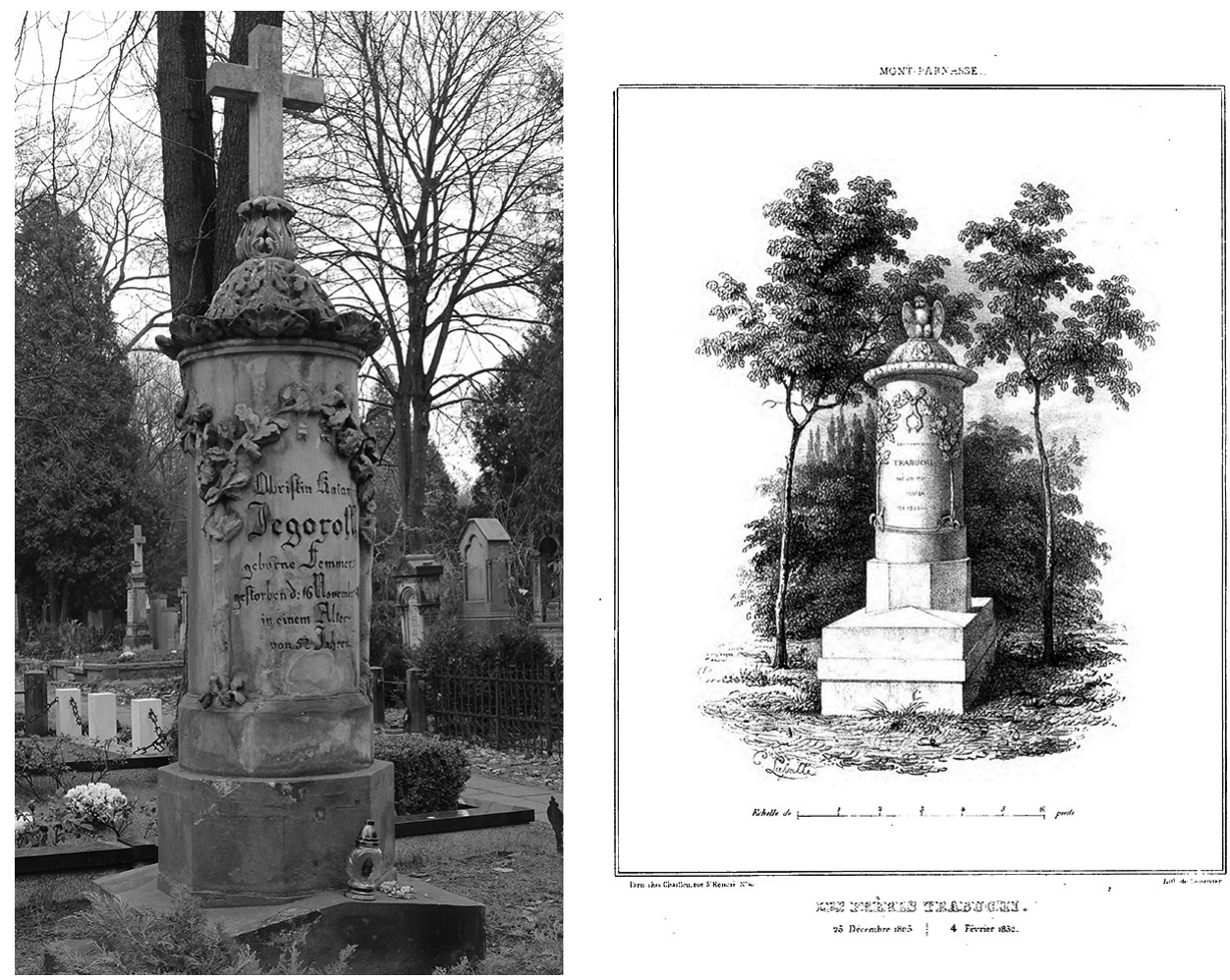

Il. 2. Pomnik Katarzyny Jegorott na cmentarzu ewang.-augsburskim oraz litografia z wzornika Marty'ego. Fot. M. Wiraszka

Ziemieckiego i Sumińskiego. Jest więc bardzo prawdopodobne, że znajdująca się w Pułtusku kopia mogła być zrealizowana w jednym z zakładów kamieniarskich w Warszawie, skąd pochodziło kilka innych obiektów zachowanych na cmentarzu św. Krzyża. Przykładem takiego importu z lat 30. XIX w. była zapewne stela Konstancji Dembowskiej, ozdobiona od frontu płaskorzeźbą żałobnicy, która składa wianek na trumnie, umieszczonej na wysokim katafalku ${ }^{14}$. Podobne formy upamiętnień, dość licznie, można bowiem spotkać na warszawskich nekropoliach ${ }^{15}$.

Oba pomniki, pod względem formy i użytych detali, cechują się niemal wiernym naśladownictwem paryskiego pierwowzoru. Steli Sumińskiego brak tylko płyty z czarnego granitu, która w wyjściowej realizacji wypełniała płycinę inskrypcyjną. Płyta granitowa nie została również wykorzystana w warszawskim nagrobku. Pomnik Ziemieckiego od francuskiego oryginału różnią ponadto trzy detale: zwieńczenie w formie krzyża, zastąpienie uskrzydlonej klepsydry dyskiem solarnym oraz wieńca laurowego wyobrażeniem węża połykającego własny ogon. Pozostałe obiekty należące do tego zespołu mają już zredukowaną

14 T.M. Rudkowski, Cmentarz Świętokrzyski..., s. 50-51, 105 (fot. nagrobka).

15 Np. na Powązkach są to pomniki: Marii ze Słupskich Stopelle (zm. 1842) - z datą w zwieńczeniu: A.D. 1842, Kazimierza Naimiskiego (zm. 1845), Teresy z Gauczów Koch (zm. 1852). 
liczbę ozdób. Owa redukcja najbardziej czytelna jest w partii cokołu, gdzie prostokątna płycina służyła częściej za miejsce do umieszczenia dodatkowego napisu niż jako obramienie dla płaskorzeźbionej lampki oliwnej ${ }^{\mathrm{j}}$. Rezygnowano też często z rozmieszczonych po jej bokach amfor ${ }^{17}$. Pomiędzy nagrobkiem Ziemińskiego i rodziny Krzemińskich występuje wyraźna zależność, polegająca na powtórzeniu w dekoracji gzymsu motywu dysku solarnego, zamiast - jak w pozostałych przykładach - uskrzydlonej klepsydry ze skrzydłami stylizowanymi na egipskie. Wyjątkiem od tej reguły jest stela małżonków Majewskich, w której skrzydła klepsydry zachowują formę typową dla sztuki zachodniej.

Dużym zainteresowaniem, tak jak poprzedni, cieszył się w Królestwie Polskim projekt architekta Louisa-Pierre'a Haudebourta (I788-I849), zrealizowany około I832 r. na paryskim cmentarzu Montmartre dla braci Trabuchi, Jacquesa-Marie (I75I - zm. 25 XII I805) i Joachima-Louisa (I758 - zm. 4 II I832). Pomnik miał formę niskiej, okrągłej podpory zakończonej półkoliście i ustawionej na ośmiokątnej podstawie, która znajdowała się na czworobocznym, trójdzielnym cokole. Dekorację zwieńczenia stanowiły liście cyprysu oraz sowa z rozpostartymi skrzydłami, która wieńczyła całość. Trzon podpory oplatały trzy pnącza dębu, którego gałązki połączone u góry wstążkami, tworzyły trzy osobne owalne pola przeznaczone na inskrypcje. Te trzy dębowe konary, zgodnie z informacją Marty’ego, miały symbolizować braterską miłość trzech braci, połączonych za życia silnymi więzami, których nawet śmierć nie mogła przerwać ${ }^{18}$.

Bracia Trabuchi przybyli z Włoch i osiedlili się w Paryżu na kilka lat przed wielką rewolucją. Fundatorem pomnika był trzeci, nieznany z imienia brat, dla którego przeznaczone było ostanie wolne miejsce na inskrypcję ${ }^{19}$. Nagrobek ten, tak jak poety Legouvè, uległ zniszczeniu podczas budowy wiaduktu.

W oparciu o ten wzór powstały w Warszawie dwa pomniki grobowe. Jeden na Cmentarzu Ewangelicko-Augsburskim przy ul. Młynarskiej dla Katarzyny z Femmersów Jegorott (al. 25, gr. I; zm. I6 XI I846) ${ }^{20}$, drugi na Powązkach dla małżonków Jelińskich herbu Nałęcz (kw. 25, rz. 6), Michała (zm. 5 IV I829) i Marii z Wodarskich (zm. 20 VIII I852) [il. 2]. Fundatorami drugiego z wymienionych były dzieci: syn Ignacy Aleksander Jeliński i córka Michalina Majewska, którzy postawili ten nagrobek po śmierci matki. Ich ojciec, z zawodu aptekarz, przeprowadził się do Warszawy z Lublina ${ }^{21}$.

\footnotetext{
16 Pomniki rodziny Witoszyńskich i małżonków Majewskich.

17 Pomniki rodzin Witoszyńskich i Krzemińskich.

18 J. Marty, dz. cyt., s. 323-325 (litografia, s. 325).

19 Tamże, s. 323.

20 Dane zaczerpnięte $\mathrm{z}$ inskrypcji w języku niemieckim umieszczonej na nagrobku.

21 MARIA JELIŃSKA z d. Wodarska, urodzona w Warszawie, córka obywatela, Bartłomieja Wodarskiego, i Anny Majewskiej, poślubiła 27 kwietnia 1822 r. Michała Jelińskiego h. Nałęcz, aptekarza, urodzonego w Lublinie. Ojciec Michała, Jan Jeliński, był dzierżawcą dochodów konsumpcyjnych. Razem z żoną, Rozalią z Pieniążków, mieszkali w Lublinie. Maria i Michał Jelińscy mieli dwoje dzieci, córkę Michalinę zamężną z Ambrożym Majewskim, właścicielem majątków ziemskich w Wolczy, a następnie w Konopnicy, oraz syna Ignacego Aleksandra. APW, Akt matzeństwa Michała Jelińskiego i Marianny Wodarskiej, Warszawa ASC Cyrkuł VII, 1822, nr 81; APW, Akt zgonu Michała Jelińskiego, par. Nawiedzenia NMP w Warszawie, 1829, nr 355; APW, Akt małżeństwa Ambrożego Majewskiego i Michaliny Jelińskiej, par. św. Krzyża w Warszawie, 1848, nr 17; [Nekrolog Marii Jelińskiej], „,Kurier Warszawski”, 1852, nr 220, s. 1159.

Zgodnie $\mathrm{z}$ informacją zamieszczoną w inskrypcji, pomnik na Powązkach ufundowały rodzicom dzieci i miało to miejsce po śmierci ich matki. Kiedy 18 października 1882 r. zmarła Michalina Majewska, w nekrologu „Kuriera Warszawskiego" pojawił się komunikat, że w dniu 31 października b.r., po mszy w kościele powązkowskim,
} 
Na cmentarzu przy ul. Lipowej w Lublinie znajdują się trzy takie same obiekty. Najstarszy, należący do Józefy z Bykowskich Eydziatowiczowej (zm. I847; sektor Va) ${ }^{22}$, powstał w zbliżonym czasie co pomnik Katarzyny Jegorott. Dwa następne wystawiono dopiero w pierwszej połowie lat 70. Prezentują one wyraźnie zapóźniony, ale ciągle podobający się na prowincji, typ nagrobka zaprojektowanego w Paryżu w trzeciej dekadzie XIX w. Są to pomniki wzniesione w miejscach pochówku doktora medycyny i chirurgii Kazimierza Mazurkiewicza (zm. I873, lat 66) i jego żony Ludwiki z Wineckich (zm. I873, lat 53; sektor VIb) ${ }^{23}$ oraz Doroty z Batowskich (zm. I874) i Stanisława Ratomskich (zm. I875; sektor I), właścicieli majątku ziemskiego ${ }^{24}$. Z Lubelszczyzny pochodzi też, stojący na cmentarzu parafialnym w Chłaniowie niedaleko Turobina, monument ozdabiający grób Seweryna Głogowskiego (zm. I862) ${ }^{25}$. Wszystkie wymienione przykłady dokładnie odwzorowują francuski prototyp. Zmianie uległa tylko forma zwieńczenia. W polskich realizacjach rzeźba sowy została zastąpiona krzyżem.

Jednoznacznym podobieństwem do pierwowzoru odznacza się też pomnik rodziny Bauerów na warszawskim cmentarzu luterańskim, który stoi pośrodku dużego pola grobowego (al. 9, gr. 37). Powstał on zapewne w drugiej połowie I846 r., po śmierci Piusa Hieronima Bauera (zm. 30 I I846), właściciela fabryki złota malarskiego, która mieściła się w Warszawie przy ul. Miodowej (nr hip. 495) ${ }^{26}$ [il. 3]. Nagrobek Bauerów nawiązuje do zachowanego na cmentarzu Père-Lachaise (div. I4) i zamieszczonego we wzorniku Marty’ego pomnika hrabiny Victoire Marie Christine Frésia d'Oglianico (zm. I8 IX I830), żony senatora Félixa Saint-Martin hrabiego de Lamotte. Projektant, francuski architekt urodzony w Rzymie, Louis Visconti (I79I-I853) ${ }^{27}$, nadał mu formę prostopadłościennej bryły nakrytej szerszym

odbędzie się „poświęcenie grobu”. Informacja powyższa odnosiła się zapewne do poświęcenia nowej krypty, ponieważ nagrobek pozostał ten sam. Przybyła mu jednie nowa inskrypcja upamiętniająca córkę nieżyjących od dawna małżonków Jelińskich. [Nekrolog Michaliny Majewskiej], „Kurier Warszawski”, 1882, nr 235, s. 6, nr 243 , s. 6.

22 M. Gmiter, B. Kotowski, K. Kucharska, B. Laskowska, L. Popek, Cmentarz rzymskokatolicki przy ul. Lipowej w Lublinie, Lublin 1990, s. 27.

23 Tamże; P. Dymel, R. Litwiński, Cmentarze lubelskie, Lublin 2015, s. 40 (fot. 5), s. 493.

24 Tamże, s. 27 i fot. 3; tamże, s. 148 (fot. 208), s. 502.

25 D. Kowałko, Cmentarze województwa zamoyskiego, Zamość 1994, s. 316.

26 PIUS Hieronim BAUER, przedsiębiorca niemiecki, do Warszawy przyjechał z miasta Hammer w Królestwie Bawarskim, był synem Jana Henryka Bauera, majstra złotniczego, i Anny Weroniki z Reslinów, małżonków tamże zamieszkałych. W wieku 31 lat ożenił się w Warszawie z Joanną Karoliną Heintz (imię używane Karolina, zm. 27 X 1850, lat 62), panną pochodzącą z cesarstwa austriackiego, córką hutnika Jana Christiana Heintza (ślub: 14 IV 1809). Najstarsza ich córka Joanna Eleonora Karolina (ur. 1810) wyszła za mąż za złotnika, Bernarda Ludwika Nasta, młodsza Anna Maria (ur. 1816) została żoną Karola Bichlera, aptekarza szpitali rządowych. Dwaj synowie: Hieronim Pius (ur. 1811; żonaty z Matyldą Amalią Nixdorf, zm. 24 VI 1906, lat 76) i Jan Henryk Ludwik (ur. 1826; ożeniony z Bronisławą Krzywicką) pracowali razem z ojcem w założonej przez niego w 1807 r. fabryce złota malarskiego i ram złoconych, która od 1827 r. mieściła się przy ul. Miodowej (nr hip. 495). Po śmierci ojca prowadzenie fabryki przejął starszy z synów, Hieronim Pius (zm. 5 II 1883, lat 72). APW, Akt matżeństwa Piusa Hieronima Bauera i Joanny Karoliny Heintz, Warszawa ASC Cyrkuł IV, 1809, nr 25; APW, Akt malżeństwa Bernarda Ludwika Nasta i Joanny Eleonory Karoliny Bauer, par. ewang.-augsburska w Warszawie, 1830, nr 58; APW, Akt matżeństwa Karola Bichlera i Anny Marii Bauer, par. ewang.-augsburska w Warszawie, 1836, nr 25; APW, Akt matżeństwa Hieronima Piusa Bauera i Matyldy Amalii Nixdorf, par. ewang.-augsburska w Warszawie, 1847, nr 16; APW, Akt matżeństwa Jana Henryka Ludwika Bauera i Bronisławy Krzywickiej, par. ewang.-augsburska w Warszawie, 1847, nr 62; [Nekrolog Piusa Hieronima Bauera], „Kurier Warszawski”, 1846, nr 31, s. 141; [Nekrolog Joanny Karoliny Bauer], „Kurier Warszawski”, 1850, nr 279, s. 1487; Fabryka złota malarskiego Bauera i Heintzów przy ul. Miodowej nr 495, „Kurier Warszawski”, 1857, nr 55, s. 291; [Nekrolog Hieronima Piusa Bauera], „Kurier Warszawski”, 1883, nr 30, s. 5; [Nekrolog Matyldy Amalii Bauer], „Kurier Warszawski”, 1904, nr 175, s. 9.

27 J. Marty, dz. cyt., s. 135-137 (litografia, s. 137). 

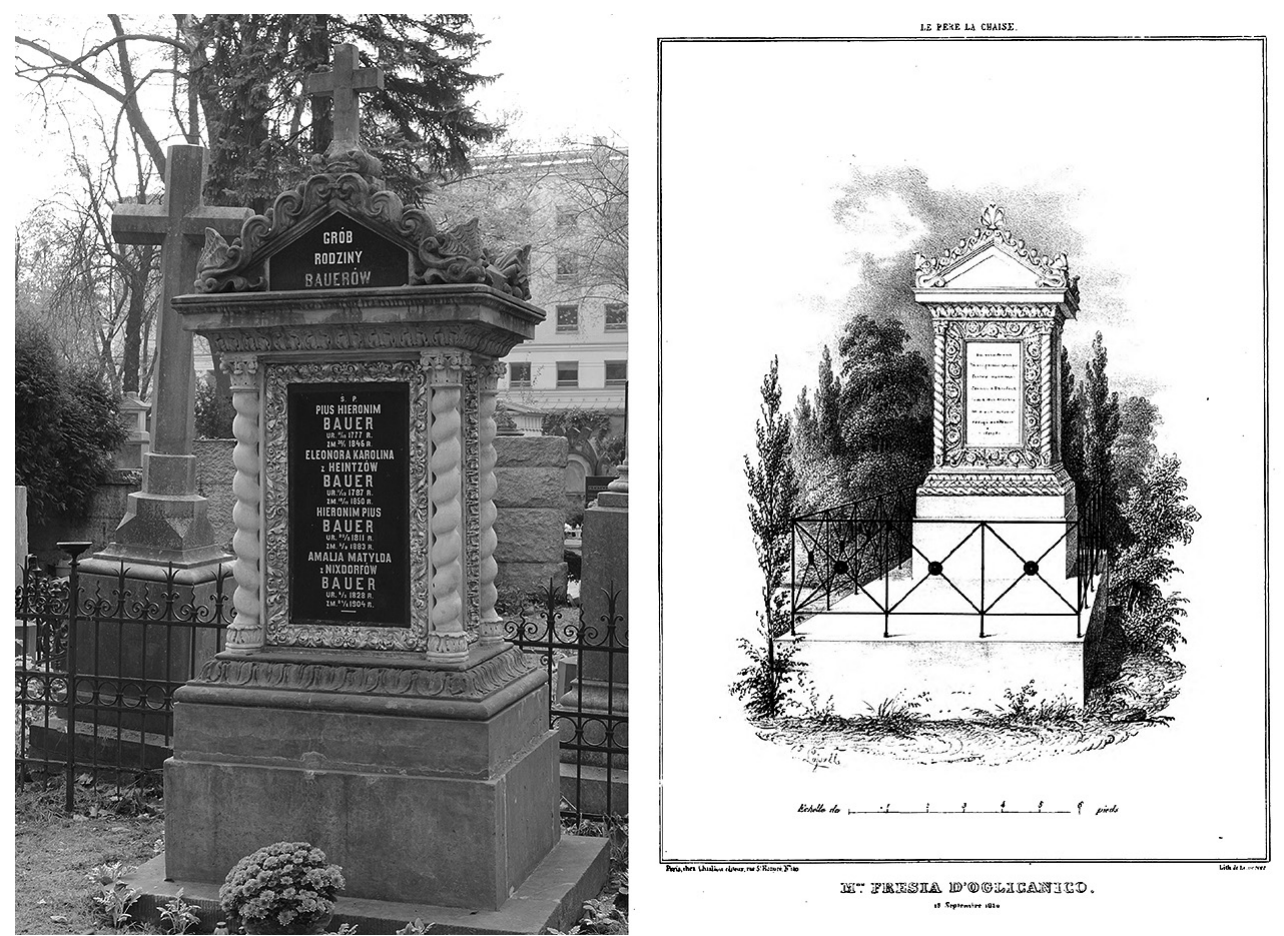

Il. 3. Pomnik rodziny Bauerów na cmentarzu ewang.-augsburskim oraz litografia z wzornika Marty'ego. Fot. M. Wiraszka

trójkątnym zwieńczeniem, które ozdobił trzema palmetami i wolutowym ornamentem z makówkami. Gładki, dwustopniowy cokół został skontrastowany z bogatym wystrojem części środkowej, której naroża podkreślają kolumienki o trzonach spiralnie skręconych, zakończone głowicami korynckimi. Pomiędzy nimi, od frontu, została umieszczona prostokątna płycina inskrypcyjna z szeroką ramą ozdobioną wicią kwiatowo-akantową.

Pomnik Bauerów, mimo iż zachowuje podstawowe cechy oryginału: proporcie, strukturę i rozmieszczenie detali, odbiega od niego sposobem wykonania elementów dekoracyjnych - niby podobnych, a jednak różnych, ponieważ wywodzących się z innych okresów stylowych. Realizacja francuska została utrzymana w stylu empire, podczas gdy nagrobkowi warszawskiemu nadano charakter bliski formom barokowym. Mógł być to przypadek, ale równie dobrze zamierzony efekt, wynikający ze świadomego odwołania się do sztuki kraju pochodzenia Bauera - Królestwa Bawarii, gdzie barok mocno odcisnął swe piętno. Złota farba, którą pomalowano ramę płyciny z inskrypcją, niekoniecznie już musiała wynikać z przyjętej stylistyki. Nawiązywała raczej do źródła utrzymania rodziny, czyli do założonej na początku XIX stulecia fabryki złota malarskiego ${ }^{28}$. W tym przypadku forma upamiętnienia stała się jednocześnie reklamą zakładu Bauera.

Louis Visconti był także twórcą monumentu Denisa Decrèsa (I76I-I820), kolejnego nagrobka, który został skopiowany na warszawskich Powązkach. Powstał on nad grobem

28 Fabryka złota..., s. 291. 
zmarłego tragiczne w Paryżu, podczas pożaru własnego domu, 7 grudnia I820 r., i pochowanego na cmentarzu Père-Lachaise (div. 39, lin. I), wiceadmirała Francji i ministra Marynarki Wojennej, który został odznaczony Wielkim Krzyżem Legii Honorowej i uhonorowany tytułem książęcym. Pomnik, ustawiony węższą stroną do alejki, ma formę wysokiego, prostopadłościennego postumentu, rozczłonkowanego pilastrami toskańskimi, na którym stoi antyczny cenotaf, zadaszony dwuspadowo i zwieńczony nad krótszymi bokami trójkątnymi naczółkami z parą akroteriów. Naroża sarkofagu dekorują cztery uskrzydlone geniusze kobiece z wiankami na głowach, które dźwigają na ramionach ciężkie girlandy laurowe, wyznaczające cztery pola przypominające kształtem tarczę. W nich znajdują się płaskorzeźby. Na krótszych bokach są to odpowiednio: od frontu herb Decrèsa z szablą honorową, z tyłu kotwica z trójzębem i kaduceuszem. Reliefy widoczne na dłuższych bokach odnoszą się do zwycięskich bitew admirała: z prawej strony przy archipelagu Les Saintes na Morzu Karaibskim - I2 kwietnia I782 r., po której szybko awansował, na lewej podczas przełamywania blokady Malty - 30 marca I800 r., za którą otrzymał szablę honorową 29.

Jako pierwszy zamieścił wizerunek nagrobka Ferdinando Quaglia w I832 r., publikując go w ujęciu frontalnym ${ }^{30}$. Pełniejszy jednak obraz pokazuje dopiero litografia znajdująca się w zbiorze Josepha Marty’ego, na której został uchwycony w widoku ent troix quatris ${ }^{31}$. Wydaje się, że wykonawca warszawskiego pomnika wzorował się na drugim wydawnictwie, ponieważ powtórzył zgodny z oryginałem podział dłuższego boku czterema pilastrami, który widoczny jest tylko na litografii Lassalle.

Projekt Viscontiego został wykorzystany przy budowie nagrobka właściciela zakładu kamieniarskiego - Jana Ścisłowskiego (zm. I3 VIII I847), który stanął na Powązkach z fun-

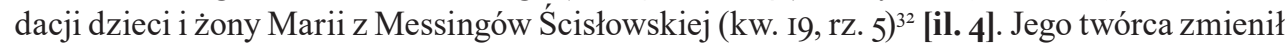
oryginalne ustawienie pomnika, wybierając na fasadę dłuższy bok zamiast krótszego. Ze zrozumiałych względów pominięto wszystkie elementy związane z biografią admirała, pozostawiając jedynie te nieodnoszące się bezpośrednio do Decrèsa. Wprowadzono też

\footnotetext{
29 J. Marty, dz. cyt., s. 87-89 (litografia, s. 89).

30 F. Quaglia, Le Père Lachaise ou Recueil de dessins au trait et dans leurs justes proportions des principaux monuments de ce cimetière, Paris 1832, pl. 18.

31 J. Marty, dz. cyt., s. 89.

32 JAN ŚCISŁOWSKI, urodzony w 1805 r. w mieście Kunów w guberni radomskiej z Jana i Wiktorii Zagórskich, małżonków Ścisłowskich, był właścicielem kamienicy i warsztatu kamieniarskiego w Warszawie, przy ul. Powązkowskiej (nr hip. 26B i 27C). Zakład funkcjonował od początku lat 30. XIX w. za rogatkami wolskimi. Początkowo mieścił się „po lewej stronie udając się z Warszawy”, a od lutego1834 r. został przeniesiony „na prawą stronę [ulicy] pod nr 27”. Żoną Ścisłowskiego była Marianna z Messingów (ur. 1812 - zm. 27 V 1904), która po śmierci męża została sama z pięciorgiem małoletnich dzieci. Warsztat kamieniarski przejął wówczas Antoni Messing (zm. 1 XI 1867, lat 46), współpracujący z Janem Ścisłowskim od początku lat 40. XIX w. Po poślubieniu w roku 1851 Joanny (zm. 17 VI 1894, lat 60), córki Jana i Marianny z Messingów, stał się jego właścicielem. Po nim warsztat przy ul. Powązkowskiej 6 odziedziczył, spokrewniony z nim, Jan Bernard Sikorski (ur. 1832 - zm. 11 II 1906), który został mężem starszej siostry Joanny, Eugenii Teofili (imię używane: Teofila; ur. ok. 1841 - zm. 12 IV 1900). [Przeniesienie warsztatu kamieniarskiego na ul. Powązkowską nr hip. 27], „Kurier Warszawski”, 1834, nr 47, s. 242; APW, Akt zgonu Jana Ścisłowskiego, par. Nawiedzenia NMP w Warszawie, 1847, nr 840; [Nekrolog Jana Ścisłowskiego], „Kurier Warszawski”, 1847, nr 217, s. 1042; APW, Akt malżénstwa Antoniego Messinga i Joanny Ścisłowskiej, par. Nawiedzenia NMP w Warszawie, 1851, nr 32; APW, Akt małżeństwa Jana Bernarda Sikorskiego i Teofili Ścisłowskiej, par. Nawiedzenia NMP w Warszawie, 1860, nr 129. Więcej na temat działalności Antoniego Messinga i Jana Sikorskiego w publikacjach: M. Wiraszka, Antoni Messing - współtwórca pomnika Najświętszej Maryi Panny przed kościolem reformatów i serii wzorowanych na nim nagrobków wzniesionych na cmentarzach Warszawy, „Saeculum Christianum”, 23/2016, s. 208-222; eadem, Kaplice i mauzolea na cmentarzach Warszawy w XIX i pierwszej połowie XX wieku, t. 1: Dzieła i ich twórcy, Warszawa 2017, s. 314-315.
} 

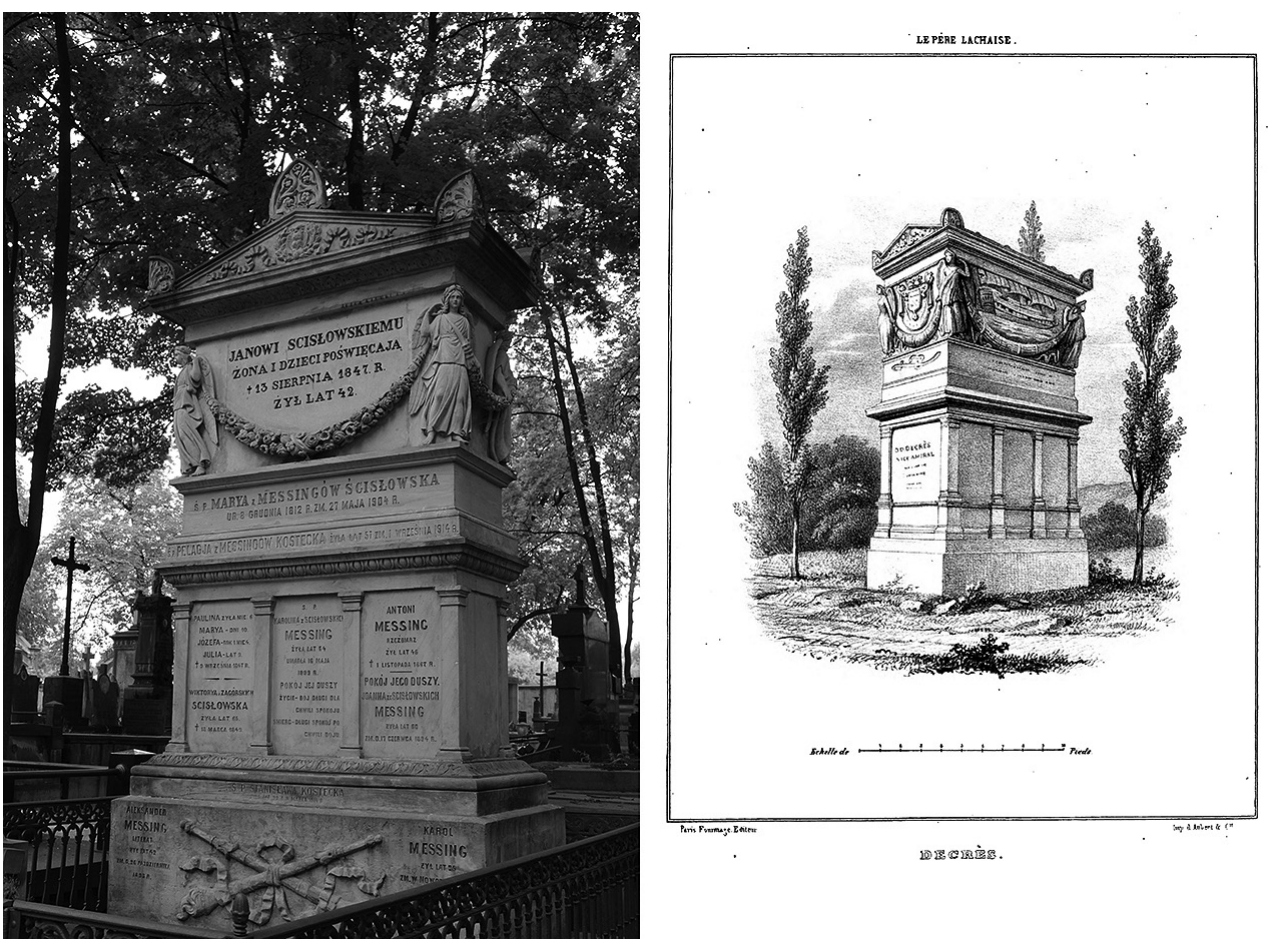

\section{Il. 4. Pomnik Jana Ścisłowskiego na Starych Powazkach oraz litografia z wzornika Marty'ego. Fot. M. Wiraszka}

drobne modyfikacje: zlikwidowane zostały postumenty pod pilastrami, laurowe girlandy zastąpiono kwiatowymi, a na cokole podstawy umieszczono, niewystępujące w pierwowzorze, dwie skrzyżowane ze sobą pochodnie, które przewiązano wstążką.

Drugi obiekt, znajdujący się na Cmentarzu Powązkowskim (kw. I2, rz. 4), który uzyskał formę zbliżoną do pomnika Decrèsa, stoi nad grobem sędziego Trybunału Handlowego, kupca win i towarów korzennych, Jana Błeszyńskiego (zm. 23 VI I849), oraz jego żony Marii z Giermanów (zm. 25 IX I849) ${ }^{33}$. Ukończony został w pierwszą rocznicę śmierci zmarłego

\footnotetext{
33 JAN i MARIA z Giermanów BŁESZYŃSCY wzięli ślub w Warszawie 27 października 1827 r. On pochodził z województwa krakowskiego, z okolic Miechowa, gdzie mieszkali i zmarli jego rodzice, Joachim i Marianna z Kwiatkowskich; ona urodziła się w Warszawie jako córka Jana Giermana, obywatela, i Anny z Ogonowskich. Jan razem z młodszym o rok bratem Ludwikiem (1799-1844) przyjechał do Warszawy na początku lat 20. XIX w. Starszy z braci zajął się handlem korzennym i sprzedażą win (sklep mieścił się przy ul. Senatorskiej nr hip. 452), którą to pracę łączył później z funkcją sędziego Trybunału Handlowego; młodszy został prezesem Sądu Kryminalnego guberni mazowieckiej i kaliskiej. Małżonkowie Błeszyńscy mieli jednego syna i sześć córek, z których tylko trzy osiągnęły wiek dorosły. Syn, także noszący imię Jan, po śmierci ojca przejął kierowanie sklepem. [Przeniesienie sklepu na ul. Senatorską], „Kurier Warszawski”, 1826, nr 163, s. 676, nr 176, s. 734; AAW, Akt małzeństwa Jana Antoniego Bteszyńskiego i Marianny Teresy Gierman, par. św. Jana Chrzciciela w Warszawie, 1827, nr 217; APW, Akt zgonu Bronisławy Bteszyńskiej, par. św. Jana Chrzciciela w Warszawie, 1832, nr 516; AAW, Akt zgonu Julii Błeszyńskiej, par. św. Jana Chrzciciela w Warszawie, 1834, nr 366; APW, Akt matżeństwa Franciszka Karola Brobka i Józefy Emilii Błeszyńskiej, par. św. Jana Chrzciciela w Warszawie, 1847, nr 181; AAW, Akt zgonu Jana Błeszyńskiego, par. św. Jana Chrzciciela w Warszawie, 1849, nr 391; AAW, Akt zgonu Marianny Bleszyńskiej, par.
} 

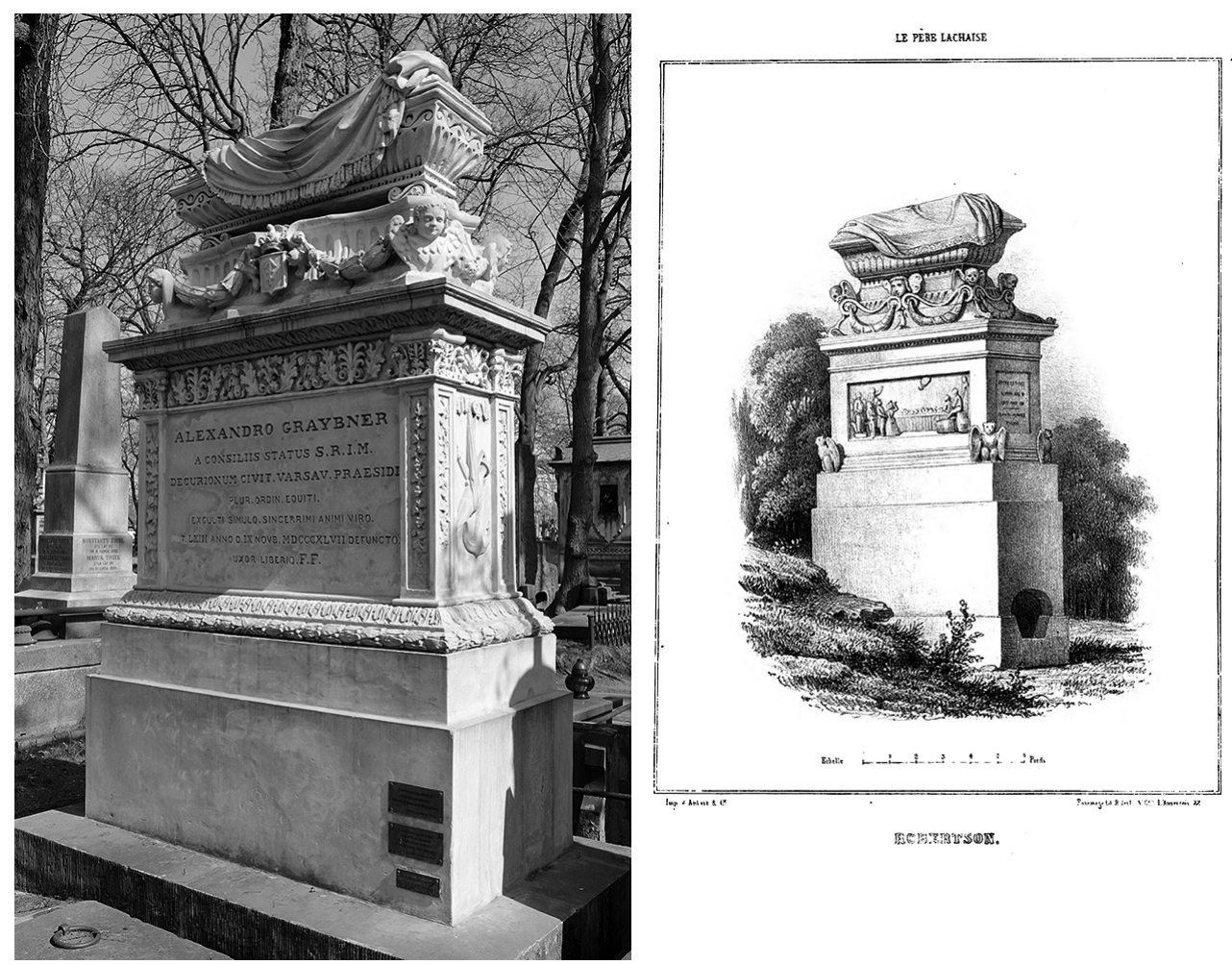

Il. 5. Pomnik Aleksandra Graybnera na Starych Powazkach oraz litografia z wzornika Marty'ego. Fot. M. Wiraszka

i poświęcony 22 czerwca I850 r.34. Wykonano go zapewne w tym samym zakładzie kamieniarskim, w którym wcześniej powstał nagrobek Ścisłowskiego. Personifikacje kobiece na obu pomnikach mają stroje przypominające grecki chiton z krótkimi rękawami i rozpuszczone, lekko kręcone włosy. W układzie kończyn górnych widoczne są podobne błędy anatomiczne. Zgięta i uniesiona nad głową ręka sprawia wrażenie jakby była pozbawiona kości. Dłonie zaś są nieproporcjonalne duże w porównaniu do reszty ciała. Wskazane podobieństwa łączą warsztatowo oba nagrobki, ale też odróżniają je we wskazanych miejscach od realizacji Viscontiego. Geniusze na pomniku Decrèsa mają bowiem włosy zebrane i upięte nad karkiem, a chitony, w które są ubrani, nie posiadają rękawów, są gęsto plisowane, zwiewne i miejscami ciasno przylegają do ciała.

Motyw uskrzydlonych postaci z przewieszonymi przez ramiona girlandami jest jedynym zaczerpniętym $z$ oryginału francuskiego elementem powtórzonym w dekoracji nagrobka małżonków Błeszyńskich. Jego twórca nie zdecydował się na odtworzenie struktury

św. Jana Chrzciciela w Warszawie, 1849, nr 585; [Nekrolog Jana Błeszyńskiego], „Kurier Warszawski”, 1849, nr 162, s. 793-794; [Nekrolog Marii Błeszyńskiej], „Kurier Warszawski”, 1849, nr 254, s. 1367; [Świeży transport minogów i łososia w składzie Jana Błeszyńskiego, ul. Senatorska 452], „Kurier Warszawski”, 1853, nr 7, s. 44.

34 „Kurier Warszawski”, 1850, nr 159, s. 849. 
architektonicznej. Zrealizowana przez niego bryła składa się z dwudzielnej podstawy o przekroju prostokąta, na której znajduje się węższy prostopadłościan zakończony parą wolut z urną okrytą kirem. Dolną część cokołu ozdabiają od przodu, umieszczone w kwadratowych płycinach, płaskorzeźbione kompozycje złożone z przeplecionych ze sobą trzech elementów: w lewej - krzyż z wieńcem dębowym i pochodnią, w prawej amfora z pochodnią i wieńcem z gałązek cyprysu.

Podobnie postąpił twórca pomnika Aleksandra Graybnera (zm. 9 XI I847) ${ }^{35}$ [il. 5]. Skopiował pojedynczy element - sarkofag na niskiej dekoracyjnej podstawie, nakryty draperią, z pominięciem architektonicznej struktury wysokiego cokołu, który występuje w oryginalnym nagrobku upamiętniającym Étienne'a Gasparda Roberta (I763-I837) na cmentarzu Père-Lachaise w Paryżu (div. 8, lin. I $)^{36}$. Pomnik na Powązkach, zamówiony po śmierci radcy stanu i prezydenta Warszawy przez dzieci i żonę Anielę ze Stanisławskich, został ustawiony na cmentarzu 9 listopada I848 r. (kw. 8, rz. 2) 37. Podstawa, na której stoi sarkofag, jest dwuczęściowa. Składa się z trójuskokowego, gładkiego cokołu i nieco od niego węższego prostopadłościanu zakończonego niepełnym belkowaniem. Gzyms z fryzem wypełniony wicią roślinną i makówkami podtrzymują narożne pilastry o głowicach korynckich i trzonach ozdobionych wąską płyciną, w której umieszczono zwisający pęd bluszczu. Na krótszych bokach znalazły się płaskorzeźbione kompozycje zawieszone na wstędze: na lewym wieniec z makówek z parą skrzyżowanych pochodni, na prawym amfora ze złamaną kotwicą. Powierzchnię dłuższych elewacji pokrywają napisy poświęcone zmarłemu, które wyryto w języku polskim i łacińskim.

Opisana podstawa powtarza strukturę architektoniczną i dekorację wcześniej wzniesionych w Warszawie nagrobków: rodzinny Nenneków na Cmentarzu Ewangelicko-Augsburskim (al. 8, gr. I5) i Ufniarskich na Powązkach (kw. 6, rz. 6). Pierwszy, przeznaczony na grób małżonków: Jana Ottona Nenneke (zm. I6 VI I837), producenta mebli pokojowych, i jego żony Anny Marianny z Breyerów (zm. 8 VIII I840) $3^{8}$, został wystawiony pomiędzy I838 a I84I r. Drugi stanął ok. I840 r. nad miejscem pochówku byłego radnego i naczelnika Wydziału Wojskowego przy Urzędzie Municypalnym m. Warszawy, Franciszka Ksawerego

\footnotetext{
35 ALEKSANDER Józef GRAYBNER herbu Lis urodził się 12 czerwca 1786 r. w Kocku na Podlasiu. Był synem Jana Henryka, kapitana artylerii konnej i szambelana króla Stanisława Augusta, i Anny z Reinschmidtów. Dwukrotnie żonaty, najpierw z Franciszką Leonorą Koprowską (zm. 22 VIII 1824), potem z Anielą Stanisławską (zm. 25 XII 1882). W życiu zawodowym zajmował wysokie stanowiska urzędnicze, będąc sekretarzem przy rządzie Królestwa Polskiego, referendarzem stanu Królestwa Polskiego, a od 20 lutego 1837 r. pełniąc obowiązki prezydenta Warszawy. Za jego kadencji został m.in. uporządkowany Cmentarz Powązkowski. APW, Akt matżeństwa Aleksandra Józefa Graybnera i Franciszki Leonory Koprowskiej, Warszawa ASC Cyrkuł II, 1817, nr 33; APW, Akt matżeństwa Aleksandra Józefa Graybnera i Anieli Stanisławskiej, par. Nawiedzenia NMP w Warszawie, 1826, nr 70; [Mianowanie na prezydenta m. Warszawy], „Kurier Warszawski”, 1837, nr 60, s. 281; APW, Akt zgonu Aleksandra Józefa Graybnera, par. św. Andrzeja w Warszawie, 1847, nr 516; [Opis pogrzebu Aleksandra Graybnera], „Kurier Warszawski”, 1847, nr 304, s. 1449; K.W. Wóycicki, Cmentarz Powąkowski pod Warszawa, t. 2, Warszawa 1856, s. 38-39; APW, Akt zgonu Anieli Graybner, par. Przemienienia Pańskiego w Warszawie, 1882, nr 201; [Nekrolog Anieli Graybner], „Kurier Warszawski” 1882, nr 289, s. 5; E. Szwankowski, Aleksander Józef Graybner (1786-1847), w: Polski Słownik Biograficzny, red. K. Lepszy, t. 8, Warszawa-Kraków-Wrocław 1959, s. 557; S. Szenic, Cmentarz Powazkowski 1790-1850. Zmarli i ich rodziny, t. 1, Warszawa 1979, s. 368, $381-382$.

36 J. Marty, dz. cyt., s. 287-289 (litografia, s. 289).

37 „Kurier Warszawski”, 1848, nr 298, s. 1437.

38 [Nekrolog Jana Otto Nenneke], „Kurier Warszawski”, 1837, nr 157, s. 769; [Nekrolog Anny Marianny Nenneke], „Kurier Warszawski”, 1840, nr 209, s. 1002, nr 212, s. 1017.
} 

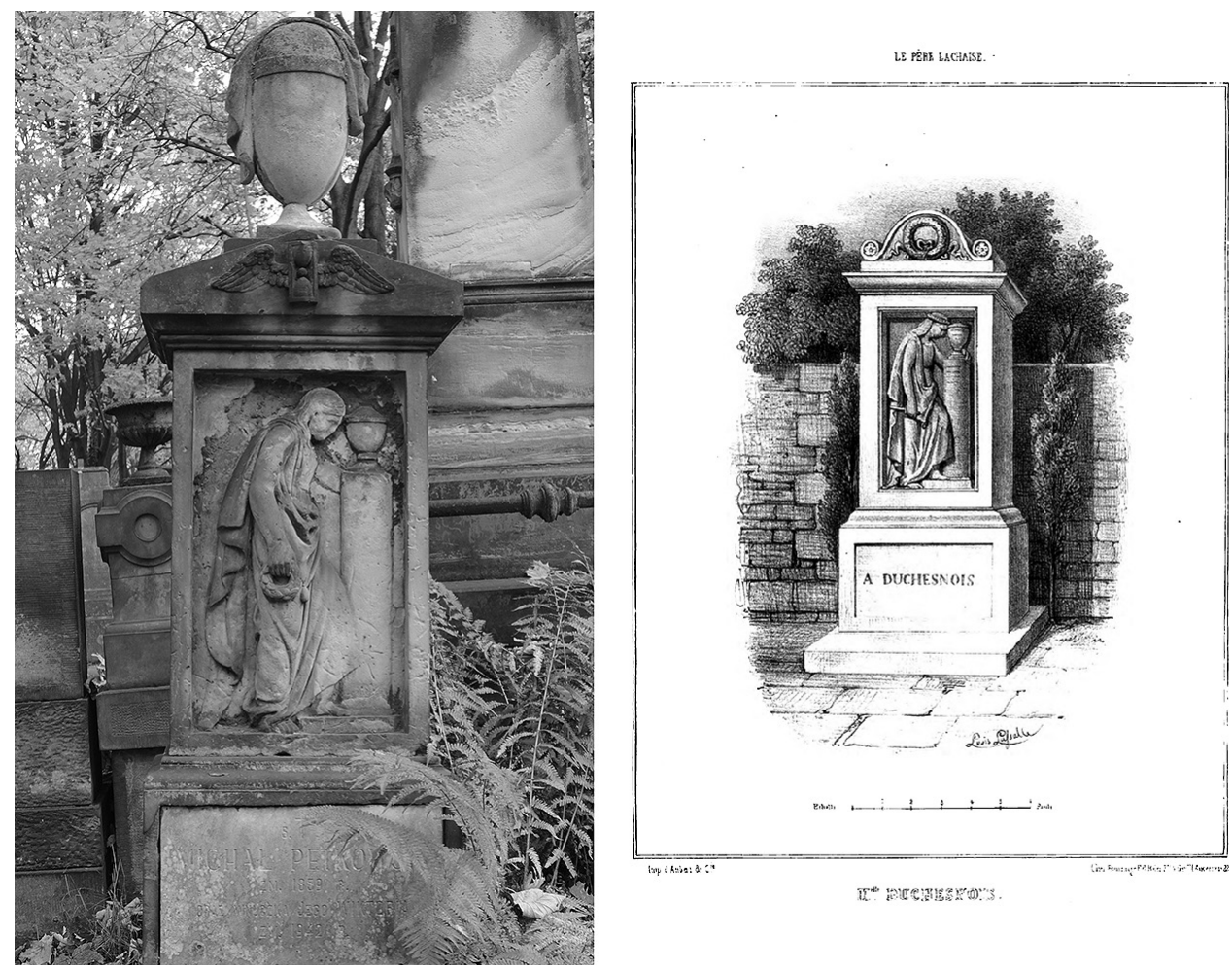

Il. 6. Pomnik Michała Pętkowskiego na Starych Powazzkach oraz litografia z wzornika Marty'ego. Fot. M. Wiraszka

Ufniarskiego (zm. IO III I840) ${ }^{39}$. Do powstania obu pomników przyczyniła się zapewne Krystyna Fryderyka z Nenneków Ufniarska, druga żona Franciszka Ufniarskiego, która była córką Jana Ottona i Anny Nenneków44. Zamówione przez nią nagrobki zostały odkute w tym samym zakładzie kamieniarskim, w którym zapewne kilka lat później wykonano pomnik Aleksandra Graybnera.

Zwieńczenie monumentu prezydenta Warszawy nie powiela niewolniczo wzorca paryskiego. Wykorzystuje tylko pomysł ustawionego na postumencie i okrytego częściowo całunem sarkofagu. Opracowanie cenotafu, draperii z frędzlami oraz dobór elementów dekoracyjnych ma już autonomiczny charakter. Zamiast głów i czaszek skrzydlatych geniuszy śmierci przy narożach podstawy sarkofagu Graybnera występują uskrzydlone główki anielskie, do których podwieszono girlandy laurowe, a pośrodku dłuższych boków umieszczono herb Lis i klepsydrę ze skrzydłami symbolizującą upływający czas. W dekoracji postumentu zrezygnowano z płaskorzeźb ze scenami lotu balonem i pokazem fantasmagorii, które obrazowały dwa istotne aspekty życia Étienne’a Gasparda Roberta (pseudonim artystyczny

39 [Nekrolog Franciszka Ufniarskiego], „Kurier Warszawski”, 1840, nr 69, s. 325, nr 75, s. 353.

40 Zob. APW, Akt malżeństwa Franciszka Ksawerego Ufniarskiego i Krystyny Fryderyki Nenneke, Warszawa ASC Cyrkuł VII, 1821, nr 15. 
Robertson) - fizyka, iluzjonisty, wynalazcy fanatyskopu i aeronauty ${ }^{41}$. Ich miejsce na nagrobku warszawskim zajęły inskrypcje.

Zbliżoną formę do warszawskiego pomnika prezentuje monument ustawiony nad grobem Franciszka Salezego Jabłońskiego (zm. 25 VII I874), referendarza stanu, ufundowany jak informuje inskrypcja: NAJLEPSZEMU OJCU przez WDZIĘCZNE DZIECI na cmentarzu parafialnym w Krzepczowie Starym niedaleko Piotrkowa Trybunalskiego ${ }^{42}$. Postument z trumną okrytą kirem stoi pośrodku trzyczęściowej podstawy o przekroju prostokąta, która zajmuje całą niemalże parcelę grobową, otoczoną dodatkowo z trzech stron ośmiobocznymi słupkami połączonymi metalowymi prętami. Pomnik został pozbawiony dodatkowych ozdób, tak charakterystycznych dla wcześniej zrealizowanych obiektów. Strukturą architektoniczną bliższy jest pomnikowi Graybnera niż oryginałowi paryskiemu. Z warszawskim nagrobkiem łączy go ponadto takie samo opracowanie wsporników trumny w formie czterech leżących wolut oraz wykorzystanie frędzli, którymi obszyto brzegi całunu. Na tej podstawie można przyjąć, że pomnik Jabłońskiego inspirowany był realizacją warszawską i zapewne w Warszawie został wykonany. Potwierdzeniem kontaktów w zakresie sztuki sepulkralnej ze stolicą w tym czasie jest pomnik Atanazego Bartoszewskiego (zm. 6 VII I874), dziedzica dóbr Kobyłek Wielkich, sygnowany przez pracownię kamieniarską Józefa Mantzla, przy ul. Chłodnej I7 w Warszawie ${ }^{43}$.

Selektywne podejście do odwzorowywanego pierwowzoru prezentuje również nagrobek Michała Pętkowskiego (zm. I859) na Cmentarzu Powązkowskim (kw. K, rz. 6) ${ }^{44}$ [il. 6]. Ma on kształt steli, którą wieńczy trójkątny naczółek z płaskorzeźbą uskrzydlonej klepsydry i urna nakryta całunem. Prostokątną płycinę niskiego cokołu, na którym stoi, wypełnia inskrypcja wyryta na tablicy z białego marmuru. Centralną część pomnika zajmuje wnęka z reliefem żałobnicy pochylonej nad urną, która znajduje się na okrągłym, wysokim słupie. Kobieta lewą ręką obejmuje podstawę naczynia, w prawej, opuszczonej swobodnie wzdłuż ciała, trzyma wianek spleciony z liści laurowych. Pierwowzorem dla tego wykonania był pomnik aktorki dramatycznej Mademoiselle Duchesnois, czyli Catherine Joséphine Duchesnois z domu Rafin (I777-I835), znajdujący się w Paryżu na cmentarzu Père-Lachaise (div. 30, lin. I), z którego został zaczerpnięty pomysł wypełnienia wnęki figuralnym reliefem ${ }^{45}$.

Płaskorzeźbę z białego marmuru wymodelował w I835 r. Philippe Joseph Henri Lemaire (I798-I880), znany rzeźbiarz francuski, autor m.in. dekoracji rzeźbiarskiej w tympanonie kościoła Marii Magdaleny w Paryżu ${ }^{46}$. Płaskorzeźba (I95XI05 cm), umieszczona na pomniku przypominającym formą starożytny słup, którymi oznaczano granice Cesarstwa Rzymskiego, przedstawia pogrążoną w smutku Melpomenę, symbolicznie nawiązującą do tragicznych ról aktorki. Jej atrybutem jest trzymany w prawej ręce sztylet. Lewą dłonią

41 J. Marty, dz. cyt., s. 287-288.

42 Informacja zaczerpnięta $\mathrm{z}$ inskrypcji umieszczonej na nagrobku.

43 Adres Chłodna 17 podany w sygnaturze jest wskazówką, że pomnik powstał przed zmianą numeracji domów w Warszawie, czyli przed 1886. Zob. M.I. Kwiatkowska, Józef Jan Mantzel - warszawski rzeźbiarz i przedsiębiorca, „Rocznik Warszawski”, 26/1996, s. 71. (Tamże błędnie podany rok zmiany numeracji domów w Warszawie $-1877)$.

44 Informacja pochodzi z inskrypcji znajdującej się na pomniku.

45 J. Marty, dz. cyt., s. 119-121 (litografia, s. 121).

46 Nagrobek, sygnowany: LEMAIRE, sculp./ MDCCCXXXV, zrealizowała spółka kamieniarska „Parisé et Deutsch". Zob. H. Jouin, La sculpture dans les cimetières de Paris, w: Nouvelles Archives de l'Art Français, t. 13, Paris 1897, s. 172. 

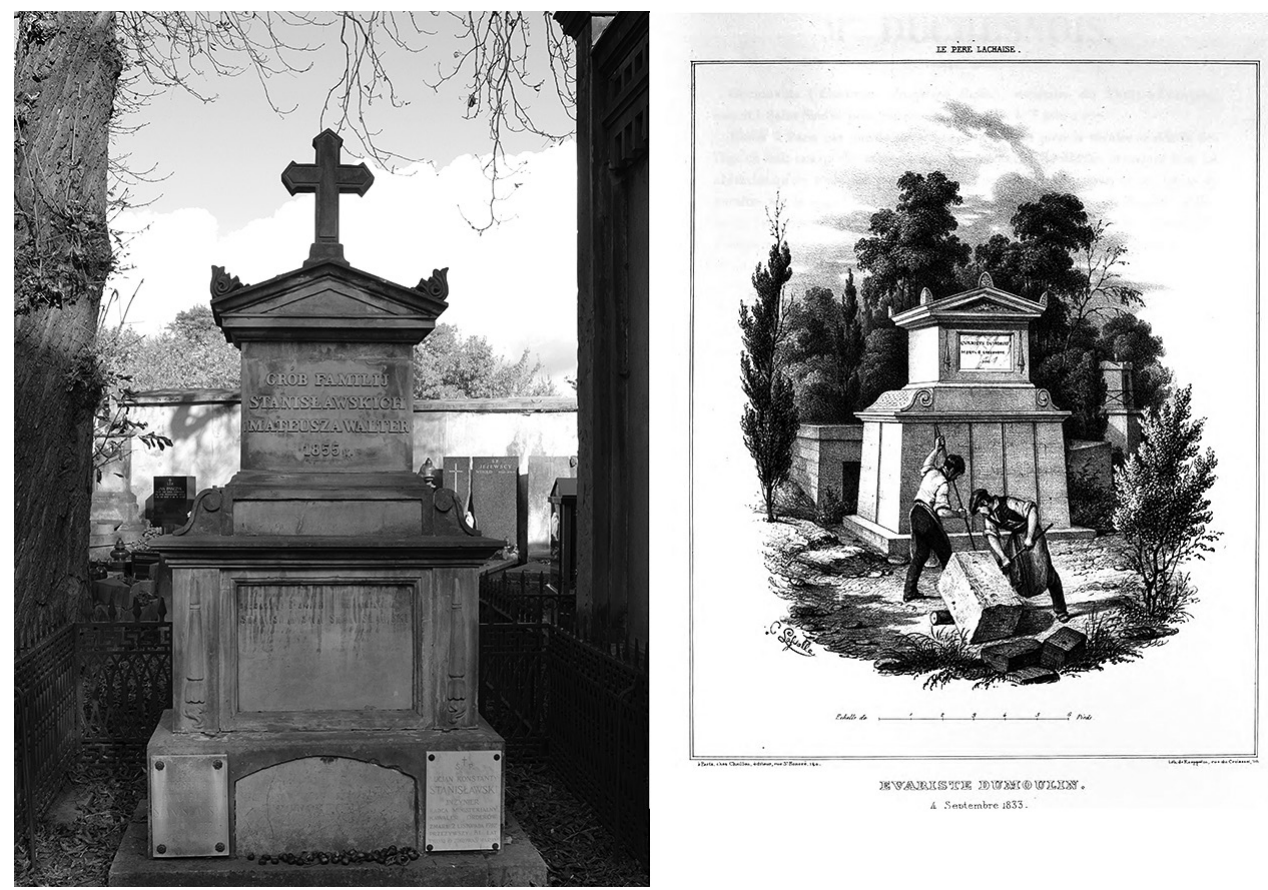

\section{Il. 7. Pomnik rodziny Stanisławskich i Mateusza Waltera oraz litografia z wzornika Marty'ego. Fot. M. Wiraszka}

opiera się na złamanej kolumnie, na której stoi urna. Na trzonie podpory wyryto tytuły tragedii, w których zagrała artystka. Pomnik został zakończony półkoliście i ozdobiony od frontu wianuszkiem wawrzynu ${ }^{47}$. Adaptacja wzorca francuskiego została ograniczona w tym przypadku do najbardziej charakterystycznego motywu, jakim jest płaskorzeźba stojącej przed słupem z urną kobiety, która dzięki odpowiednio dobranym atrybutom raz jest muzą tragedii, drugim razem płaczką - żałobnicą.

Ostatni z odnalezionych w Warszawie przykładów inspirowany wzornikiem Marty’ego powstał w I855 r. Został wzniesiony na Cmentarzu Powązkowskim (kw. 25 wprost, rz. I) po śmierci Mateusza Waltera (zm. 23 II I855) i poświęcony 23 października w obecności przyjaciół zmarłego ${ }^{48}$. Fundatorami pomnika byli małżonkowie Barbara z Sielskich (zm. 20 IX I865) i Franciszek Stanisławski (zm. 23 II I883), z zawodu szewc, którzy tu później zostali pochowani ${ }^{49}$ [il. 7]. Nagrobek wzorowany na pomniku publicysty Évariste'a Pierre'a Latoura Dumoulina (I787-I833), pochowanego na cmentarzu Père-Lachaise (div. 39, lin.I) ${ }^{50}$, składa się, podobnie jak oryginał, z dwóch części. Dolnej, która w realizacji francuskiej

\footnotetext{
47 J. Marty, dz. cyt., s. 119-121.

48 „Kurier Warszawski”, 1855, nr 220, s. 1130; APW, Akt zgonu Mateusza Waltera, par. św. Andrzeja w Warszawie, 1855, nr 121; [Nekrolog Mateusza Waltera], „Kurier Warszawski”, 1855, nr 53, s. 253.

49 APW, Akt urodzenia Agnieszki Stanisławskiej, par. św. Andrzeja w Warszawie, 1829, nr 66; [Nekrolog Barbary Stanisławskiej], „Kurier Warszawski”, 1865, nr 215, s. 1133; [Nekrolog Franciszka Stanisławskiego], „Kurier Warszawski", 1883, nr 45, s. 5 .

50 J. Marty, dz. cyt., s. 115-117 (litografia, s. 117).
} 
przybrała formę trapezoidalną, podzieloną żłobkowaniem na pionowe gładkie pasy, w polskiej prostopadłościenną na dwuuskokowym cokole, z parą płycin wypełnionych marmurowymi tablicami inskrypcyjnymi. Zwieńczenie dolnej części pomnika stanowi drobno profilowany gzyms. Powyżej niego znajduje się węższy prostopadłościan ustawiony na niskim cokole, ujęty po bokach spływami wolutowymi i zakończony trójkątnym naczółkiem z akroteriami. W polskim wykonaniu pomnik został zwieńczony krzyżem, we francuskim ozdobiony prostokątną płyciną z inskrypcją flankowaną pochodniami. Odwrócone płomieniem do dołu pochodnie występują również na warszawskim nagrobku. Zostały jednak umieszczone w dolnej kondygnacji, po bokach płyciny inskrypcyjnej. Twórca pomnika rodziny Stanisławskich i Mateusza Waltera powtórzył zatem z niewielkimi zmianami z oryginalnego projektu formę wyższej kondygnacji, dolną zaś opracował samodzielnie, wprowadzając dodatkowe miejsca na umieszczenie napisów.

Zgromadzony i omówiony w dwóch osobnych artykułach materiał zabytkowy, pozwala stwierdzić, że w okresie między I840 a I860 r. na cmentarzach Warszawy powstało co najmniej dwadzieścia obiektów wzorowanych na litograficznych odbitkach nagrobków, które opublikowane zostały w Paryżu w I832 i I839 r. przez Ferdinanda Quaglię, Louisa Marie Normanda i Josepha Marty’ego. Przykłady zebrane w tych trzech wydawnictwach pochodzą z lat 20. i 30. XIX w. i znajdują się lub znajdowały się na paryskich nekropoliach. Utrzymane w stylistyce empiru, która była wówczas oficjalną sztuką cesarskiego dworu, prezentują formy inspirowane zabytkami starożytnej Grecji, Rzymu i Egiptu. Ich twórcami byli często bardzo znani architekci francuscy: Louis Visconti (I79I-I853), Étienne Hippolyte Godde (I78I-I869) oraz rzeźbiarze: François Joseph Bosio (I768-I845), Nicolas Bernard Raggi (I790-I862), Philippe Joseph Henri Lemaire (I798-I880).

Najwięcej, bo aż czternaście przykładów zachowało się na Cmentarzu Powązkowskim, trzy następne odnaleziono na Cmentarzu Ewangelicko-Augsburskim oraz dwa na Cmentarzu Ewangelicko-Reformowanym. Kopie nagrobków inspirowane francuskimi wydawnictwami ilustrowanymi występują również poza Warszawą. Wstępne badania inwentaryzacyjne potwierdziły ich obecność na cmentarzach: w Lublinie, Pułtusku, Chełmicy Dużej k. Włocławka, Radomiu, Krzepczowie Starym (pow. piotrkowski) i Chłaniowie k. Turobina. Są to na ogół te same wzory, które w Warszawie cieszyły się największą popularnością. Można zatem przypuszczać, że źródłem ich rozpowszechniania mogła być stolica. Za importy należy przede wszystkim uznać te pomniki, których czas wzniesienia przypadł na ok. połowę XIX stulecia. Późniejsze, powstałe w latach 60. i 70., mogły być już wykonane przez lokalnych rzemieślników na wzór istniejącego na miejscowym cmentarzu nagrobka ${ }^{51}$.

W Warszawie formy francuskie z całą pewnością realizowane były za pośrednictwem ilustrowanych wydawnictw. Różnice, jakie występują pomiędzy oryginalnym wyglądem nagrobka a jego litograficzną odbitką, wykluczają możliwość bezpośredniego naśladownictwa. Zmiany najlepiej widoczne są w przykładach, w których istotnym elementem dekoracji były przedstawienia figuralne. Postacie prezentowane na płaskorzeźbach zwrócone są do widza inną stroną ciała, prawostronnie - na litografiach i lewostronnie - w oryginalnych ujęciach. Ponadto wizerunki graficzne cechują się uproszczeniem form i redukcją detali w porównaniu

${ }^{51}$ Za przykład mogą posłużyć pomniki na cmentarzu rzymskokatolickim przy ul. Lipowej w Lublinie: Józefy Eydziatowiczowej, powstały zapewne w połowie XIX w., oraz pochodzące z lat 70. tego samego stulecia nagrobki małżonków Mazurkiewiczów i rodziny Ratomskich, a także na cmentarzu rzymskokatolickim w Radomiu, powstały ok. 1878 pomnik Brandtów i wzniesiony na początku XX w., grobowiec Pinków. 
z oryginalnymi realizacjami. Przykładowo, w pomniku Mademoiselle Duchesnois, znajdującym się na Père-Lachaise, Melpomena obejmująca prawą ręką trzon kolumny, na którym stoi urna, trzyma jeszcze w dłoni gałązkę cyprysu. Detalu tego nie ma na litografii, przez co nie mógł być on również zrealizowany w nagrobku Michała Pętkowskiego na Cmentarzu Powązkowskim.

Wszystkie trzy opracowania pojawiły się w Warszawie w podobnym czasie. Pierwsze pomniki ustawiono na cmentarzach stołecznych na przełomie lat 30. i 40. XIX w. Najstarsze zachowane przykłady pochodzą z wzornika Normanda i zostały wykorzystane między I836 a I838 r. przy wznoszeniu nagrobków Ignacego Zielińskiego (zm. 23 VIII I835) na Powązkach i Adolfa Petyskusa (zm. 8 II I836) na cmentarzu luterańskim² ${ }^{52}$ Nieco późniejsze są obiekty oparte na wzorach zaczerpniętych z wydawnictw ilustrowanych Quaglii i Marty’ego. Znajdują się one na Cmentarzu Powązkowskim. W pierwszym przypadku można wskazać, pochodzący z I846 r., monument poświęcony rodzeństwu Sokołowskich, Emilii (zm. I6 VII I837) i Aleksandrowi (zm. I2 VII I845) ${ }^{53}$, w drugim nagrobek Franciszka Ziemieckiego (zm. 2 XII I843), który został ukończony pod koniec roku I844.

Wśród zamawiających największą popularnością cieszył się zbiór Josepha Marty’ego, z którego wykorzystano aż siedem przykładów, realizując łącznie I9 obiektów - trzynaście w stolicy, po jednym na Mazowszu i ziemi sieradzkiej oraz cztery na Lubelszczyźnie. Szczególnie dwa nagrobki, pochodzące z tej publikacji, spodobały się polskim odbiorcom. Jeden w formie steli, zwieńczony gzymsem cavetto i trójkątnym naczółkiem z akroteriami, mieszczący pośrodku prostokątną płycinę flankowaną parą pochodni i ozdobiony w partii cokołu dwoma amforami i kagankiem oliwnym, oraz drugi w postaci okrągłej podpory, ustawionej na czworobocznym cokole, dekorowany trzema płaskorzeźbionymi pnączami dębu. Według pierwszego wzoru wykonano w Warszawie pięć obiektów, wszystkie na Starych Powązkach, oraz jeden w Pułtusku na Cmentarzu Świętokrzyskim. Drugi skopiowano w stolicy dwukrotnie, wznosząc pomniki na Cmentarzach Powązkowskim i Ewangelicko-Augsburskim; poza Warszawą jeszcze trzy nagrobki stanęły w Lublinie, na cmentarzu rzymskokatolickim przy ul. Lipowej, i jeden na cmentarzu parafialnym w Chłaniowie k. Turobina.

Odnalezione na stołecznych nekropoliach monumenty reprezentują trzy podejścia w sposobie odwzorowania form francuskich. Najliczniejsze są nagrobki, w których starano się skopiować zarówno strukturę architektoniczną jak również rodzaj i rozmieszczenie elementów dekoracyjnych. Drugie miejsce zajmują obiekty, w których wiernie powtórzono z oryginalnego projektu co najmniej jedną, charakterystyczną część jego kompozycji. Najmniej liczne są przykłady, łączące elementy zaczerpnięte z dwóch lub większej liczby nagrobków54.

Ufundowane przez rodziny lub przyjaciół pomniki powstawały nad grobami osób zamożnych: wysokich rangą urzędników państwowych: Ignacego Zielińskiego - prezesa Najwyższej Izby Obrachunkowej; Franciszka Ziemieckiego - radcy skarbowego; Bonawentury Adamowskiego - referenta w Biurze Rady Administracyjnej Królestwa Polskiego;

\footnotetext{
52 Zob. M. Wiraszka, Wykorzystanie publikacji..., s. 48-49 (il. 1, s. 44), s. 55-57 (il. 4, s. 52).

53 Tamże, s. 49-50 (il. 2, s. 49).

54 Przykładem realizacji drugiego typu są pomniki: Ignacego Zielińskiego, Wacława Sierakowskiego, rodzeństwa Sokołowskich, Karola Fryderyka Woydy, małżonków Majewskich, rodziny Witoszyńskich i Winklerów, Aleksandra Graybnera, małżonków Błeszyńskich, rodziny Stanisławskich i Michała Pętkowskiego. Wariant trzeci reprezentowany jest przez jeden nagrobek Adolfa Petyskusa. Pozostałe pomniki w liczbie szesnastu ilustrują pierwszy ze wskazanych typów. Zob. Zestawienia pomników.
} 
Jana Majewskiego - radcy stanu i członka intendentury wojskowej; Franciszka Salezego Jabłońskiego - referendarza stanu; prezydentów Warszawy - Karola Fryderyka Woydy i Aleksandra Graybnera; generałów - Michała Włodka i Wacława Sierakowskiego; właścicieli fabryk i warsztatów - Piusa Hieronima Bauera i Jana Ścisłowskiego; właścicieli nieruchomości - Adolfa Petyskusa i Mateusza Krzemińskiego; kupców - rodziny Sokołowskich i Błeszyńskich oraz przedstawicieli wolnych zawodów: lekarzy, aptekarzy, jubilerów, literatów i malarzy - rodziny Jelińskich, Tripplinów, Winklerów, Brandtów oraz Pinków.

O wyborze nagrobka decydowały zasobność portfela i gust zamawiającego. Jedynie o obelisku Michała Włodka, można powiedzieć, że dobór wzorca warunkowany był czymś więcej niż tylko piękną formą pomnika marszałka Francji, André Massény. O jego powtórzeniu zdecydowały również, a może przede wszystkim, podobne życiorysy obu mężów stanu, wysokich rangą wojskowych, odznaczonych wieloma medalami i uhonorowanych licznymi zaszczytami za zwycięskie kampanie ${ }^{55}$.

Żaden z opisanych nagrobków warszawskich nie jest sygnowany. Publikacje dziewiętnastowieczne odnotowały nazwisko tylko jednego twórcy, Jakuba Tatarkiewicza, który wymodelował popiersie przeznaczone do pomnika Michała Włodka. Rzeźbiarz nie był jednak wykonawcą obelisku. Przeczy temu informacja zamieszczona w „Kurierze Warszawskim”, gdzie podano, że pomnik powstał „w fabryce jednego z tutejszych kamieniarzy ${ }^{\prime 56}$. To w tej grupie zawodowej należy upatrywać głównych popularyzatorów francuskich wzorników i wykonawców kopii paryskich nagrobków, którymi ozdobiono warszawskie jak i pozastołeczne cmentarze.

Jednym z nich mógł być Jan Ścisłowski (I805-I847), właściciel kamienicy (nr hip. 26 B) i warsztatu kamieniarskiego (nr hip. 27 C) przy ul. Powązkowskiej 6. Z tego zakładu pochodził bowiem grobowiec, który wyglądem przypominał nagrobki zamieszczone w publikacjach Quaglii - Jeana Alexandre'a Gervaisa Hennecarta (pl. 4) s7 $^{5}$ Normanda - Tiburce'a Pierre'a Morisota (pl. 48) 58 $^{58}$ oraz zrealizowane na ich wzór na cmentarzu rzymskokatolickim w Radomiu pomniki dla rodzin Brandtów (ok. I878) oraz Pinków (kon. XIX w.) (59 $^{\text {. Monument }}$ był przeznaczony dla zmarłego w Płocku i pochowanego w majątku żony, na cmentarzu parafialnym w Chełmicy Dużej pod Włocławkiem, generała Wacława Sierakowskiego (I788-I839) ${ }^{60}$. Wystawiła go żona, Józefa z Rutkowskich (ok. I807-I876), która była również fundatorką umieszczonej na nim tablicy dedykowanej ich synowi, Wacławowi Maksymilianowi Sierakowskiemu (I828-I870) ${ }^{61}$.

Grobowiec ma formę okazałego sześcianu. Został wzniesiony z cegły otynkowanej i uzupełniony w partiach gzymsu cokołowego, zwieńczenia i elementów dekoracyjnych - piaskowcem.

\footnotetext{
55 Zob. M. Wiraszka, Wykorzystanie publikacji..., s. 50-55.

56 Tamże, s. 53. „Kurier Warszawski”, 1851, nr 138, s. 718.

57 F. Quaglia, dz. cyt., pl. 4.

58 L.M. Normand, Monuments funéraires choisis dans les cimetières de Paris et des principales villes de France, Paris 1832, pl. 48.

59 M. Wiraszka, Wykorzystanie publikacji..., s. $57-59$ (il. 6 i 7, s. 56 i 58).

60 [Nekrolog Wacława Sierakowskiego], „Kurier Warszawski”, 1839, nr 220, s. 1061-1062; Z. Zacharewicz, Wacław Sierakowski (1788-1839), w: Polski Słownik Biograficzny, red. H. Markiewicz, t. 37, Warszawa 1996-1997, s. 315 .

${ }_{61}$ M. Omilanowska, Uzupetnienie: Chetmica Duża, w: Katalog Zabytków Sztuki w Polsce, t. XI: Województwo bydgoskie, red. T. Chrzanowski, M. Kornecki, z. 18: Włoctawek i okolice, opr. M. Paździor, W. Puget, T. Chrzanowski, M. Kornecki, Z. Rozanow, Warszawa 1988, s. 192.
} 
Każda z elewacji została zakończona podwójnym trójkątnym frontonikiem z akroteriami. Tympanony wypełniono uskrzydlonymi klepsydrami, wieńcami laurowymi oraz herbami Pobóg Rutkowskich i Dołęga Sierakowskich. Dekoracji jednego z boków, na którym zachowała się tablica poświęcona Sierakowskiemu, dopełniają odwrócone płomieniem do dołu pochodnie, które umieszczono wzdłuż bocznych krawędzi. Możliwe, że pochodnie, zgodnie z kompozycją widoczną na litografiach Quaglii i Normanda, znajdowały się również pośrodku każdego boku oraz zostały powtórzone symetrycznie przy narożach pozostałych elewacji. Jednoznacznie nie można tego stwierdzić z powodu nie najlepszego stanu zachowania pomnika, któremu brakuje m.in. inskrypcji innych pochowanych w nim osób.

Grobowiec Sierakowskich w Chełmicy Dużej jest jedyną znaną pracą Jana Ścisłowskiego przeznaczoną do ustawienia na cmentarzu. Dwa następne przykłady powiązane z nazwiskiem kamieniarza zachowały się we wnętrzach świątyń. Są to marmurowe epitafia poświęcone senatorowi Królestwa Polskiego, Antoniemu Gliszczyńskiemu (zm. 25 XII I835), w kościele parafialnym w Łaniętach i Stanisławowi Podleckiemu w kościele w Błoniu ${ }^{62}$. Dotąd nie udało się zidentyfikować żadnych realizacji na terenie Warszawy. Wiadomo tylko, że nagrobek Ścisłowskiego, wystawiony po jego śmierci na Cmentarzu Powązkowskim przez żonę i dzieci, również był kopią znajdującego się na Père-Lachaise i opublikowanego przez Josepha Marty’ego pomnika. Wykonawcą warszawskiego nagrobka był zapewne Antoni Messing (I82II867), wieloletni współpracownik Ścisłowskiego, a później właściciel odziedziczonego po nim warsztatu przy ul. Powązkowskiej ${ }^{63}$. Jemu też należałoby przypisać realizację pomnika Jana Błeszyńskiego, ukończonego w I850 r.

Po Messingu, kontynuatorem form francuskiego empiru w sztuce sepulkralnej Warszawy lat 70. XIX w. mógł być Jan Bernard Sikorski (I832-I906), kolejny właściciel zakładu na Powązkach, który tak jak poprzednik ożeniony był z córką Jana Ścisłowskiego i Marii z Messingów ${ }^{64}$. Z nim można byłoby związać autorstwo radomskiego pomnika Anny Krystyny z Lesslów Brandt (zm. I7 V I878). Pomnik Brandtów nie jest bowiem jedynym śladem działalności Sikorskiego w Radomiu. Dla tamtejszego cmentarza rzymskokatolickiego kamieniarz wykonał jeszcze nagrobek z figurą Chrystusa przeznaczony na grób rodziny Sędzikowskich (kon. XIX, kw. 2B). W tym przypadku autorstwo Sikorskiego potwierdza sygnatura $^{65}$.

Zakład kamieniarski przy ul. Powązkowskiej nie był wyłącznym wykonawcą nagrobków pochodzących z francuskich wydawnictw ilustrowanych. Korzystała z nich również firma Mantzlów, której warsztat kamieniarsko-rzeźbiarski mieścił się przy ul. Chłodnej I9 (nr hip. 927 B) ${ }^{66}$. Stamtąd wyszły m.in. stojące na Powązkach pomniki: prezesa sądu kryminalnego Ludwika Błeszyńskiego (pośw. 20 IV I846; kw. I2, rz. 4) ${ }^{67}$, kupca i sędziego Trybunału

${ }^{62}$ M.I. Kwiatkowska, Rzeźbiarze warszawscy XIX wieku, Warszawa 1995, s. 59.

63 Zob. M. Wiraszka, Antoni Messing..., s. 208-222.

64 Zob. M. Wiraszka, Kaplice i mauzolea..., s. 314-315.

65 R.K. Bochyński, Plastyka nagrobkowa, w: Cmentarz rzymskokatolicki w Radomiu przy dawnym Trakcie Starokrakowskim obecnie ul. B. Limanowskiego, red. R. Brykowski, Radom 1997, s. 42.

66 Przed 1886 r., czyli przed zmianą numeracji domów w Warszawie, warsztat miał adres Chłodna 17. Więcej na temat zakładu i twórczości Mantzlów w opracowaniach Marii I. Kwiatkowskiej i Tadeusza M. Rudkowskiego. M.I. Kwiatkowska, Rzeźbiarze..., s. 58-59, 196-201; eadem, Józef Jan Mantzel..., s. 47-76; T.M. Rudkowski, Cmentarz Powazkowski w Warszawie. Panteon Polski, Wrocław 2014, s. 99-106.

${ }^{67}$ Ludwik Błeszyński (zm. 13 IV 1844) był młodszym bratem Jana Błeszyńskiego. Informacja o autorstwie pomnika, ustawionego na Powązkach w drugą rocznicę śmierci zmarłego, została zamieszczona w „Kurierze War- 
Handlowego Józefa Rostropowicza (ok. I847-I848; kw. 2, rz. 6$)^{68}$ oraz rodziny Tokarskich (I87I; kw. I8I, rz. 5) ${ }^{69}$. Pierwsze dwa wykonał Jan Józef Mantzel (I8o6-I875), ostatni był dziełem jego syna Józefa Jana (I834-I906). Wszystkie reprezentują ten sam typ nagrobka w formie neogotyckiej wieżyczki, ozdobionej licznymi płaskorzeźbami i figurami świętych. Pierwowzór, odnaleziony przez Wiesława Procyka, pochodził z cmentarza Père-Lachaise i został zamieszczony w I2 zeszycie niemieckiego wydawnictwa Der Friedhof Allgemeines Musterbuch ausgeführter Grab - Denkmäler und Monumente, który ukazał się w latach I859-I86I ${ }^{70}$. Rok wydania publikacji wyklucza ją jednak jako źródło, z którego zaczerpnięto wzór dla nagrobków powązkowskich. Jej wydanie nastąpiło bowiem później, niż powstały pierwsze dwa pomniki na Powązkach. Mantzel musiał skorzystać zatem z innego, nieznanego wzornika, w którym umieszczono paryski nagrobek. Możliwe, że to właśnie z tej pracowni wyszedł pomnik Franciszka Salezego Jabłońskiego, który inspirowany był powązkowskim pomnikiem prezydenta Warszawy, Aleksandra Graybnera. W tym samym czasie co Jabłonowskiego został zrealizowany przez Józefa Mantzla nagrobek Atanazego Bartoszewskiego na tym samym cmentarzu w Krzepczowie Starym.

Zaprezentowane wydawnictwa francuskie Ferdinanda Quaglii, Louisa Marie Normanda i Josepha Marty'ego z I832 i I839 r. odegrały znaczącą rolę w kształtowaniu sztuki sepulkralnej Warszawy i Królestwa Polskiego. Ich wpływ widoczny był szczególnie w latach I840-I860. Poza stolicą z wzorów tych korzystali kamieniarze jeszcze do połowy lat 70. XIX w. Oferta warszawskich zakładów kamieniarskich była odzwierciedleniem gustu elit, w większości katolików pochodzenia szlacheckiego, który był wyrazem profrancuskich sympatii tej warstwy społecznej i zarazem podziwu dla wyższości tejże kultury, sięgającej czasów panowania Ludwika XIV. Uczucia te zostały jeszcze mocniej rozbudzone na przełomie XVIII i XIX w. przez cesarza Francuzów Napoleona Bonaparte nadzieją odzyskania przez Polskę niepodległości.

\footnotetext{
szawskim”. [Nekrolog Ludwika Błeszyńskiego], „Kurier Warszawski”, 1844, nr 100, s. 469; 1846, nr 103, s. 485, nr 107, s. 509.

68 Pomnik Józefa Rostropowicza (zm. 23 V 1847), ze względu na podobieństwo do pomnika Ludwika Błeszyńskiego i zbliżony czas powstania, został przypisany zakładowi kamieniarskiemu przy ul. Chłodnej przez Tadeusza M. Rudkowskiego. T.M. Rudkowski, Cmentarz Powazkowski..., s. 99-101.

69 Autorstwo pomnika Tokarskich potwierdza zarówno sygnatura jak i wzmianka w „Kurierze Warszawskim” odnosząca się do czasu jego powstania. Tamże, s. 105; „Kurier Warszawski”. 1872, nr 1, s. 2.

70 W. Procyk, XIX-wieczny wzornik pomników nagrobnych. Próba określenia sposobów i zakresu wykorzystania wzorów na cmentarzu powazkowskim, w: Cemetery Art - Sztuka cmentarna - L'art de cimetière. Dokumenty sympozjum naukowego, 28-30 października 1993 r., red. O. Czerner, I. Juszkiewicz, Wrocław 1995, s. 281.
} 


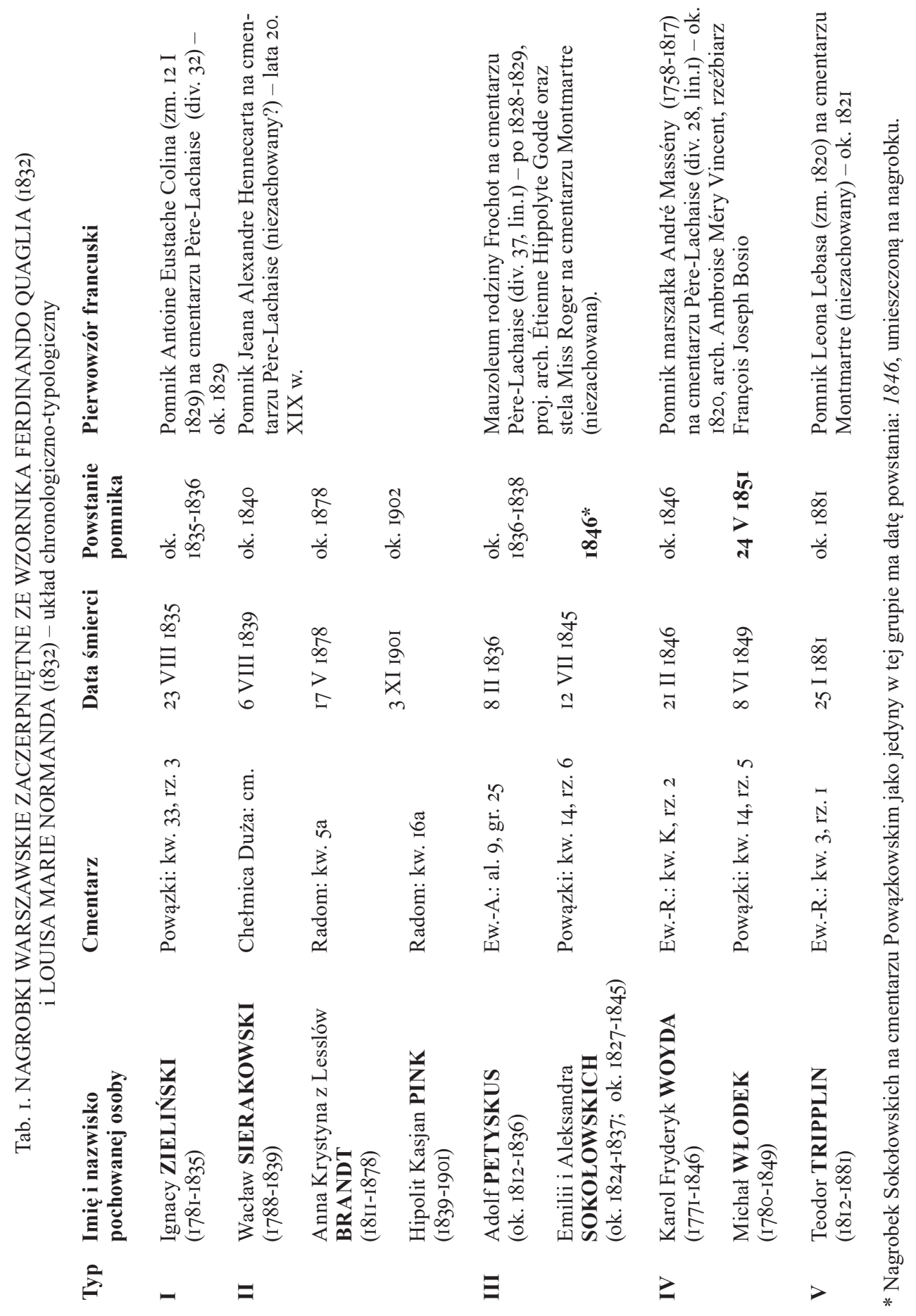


WYKORZYSTANIE PUBLIKACJI FRANCUSKICH PRZY REALIZACJI NAGROBKÓW... 305

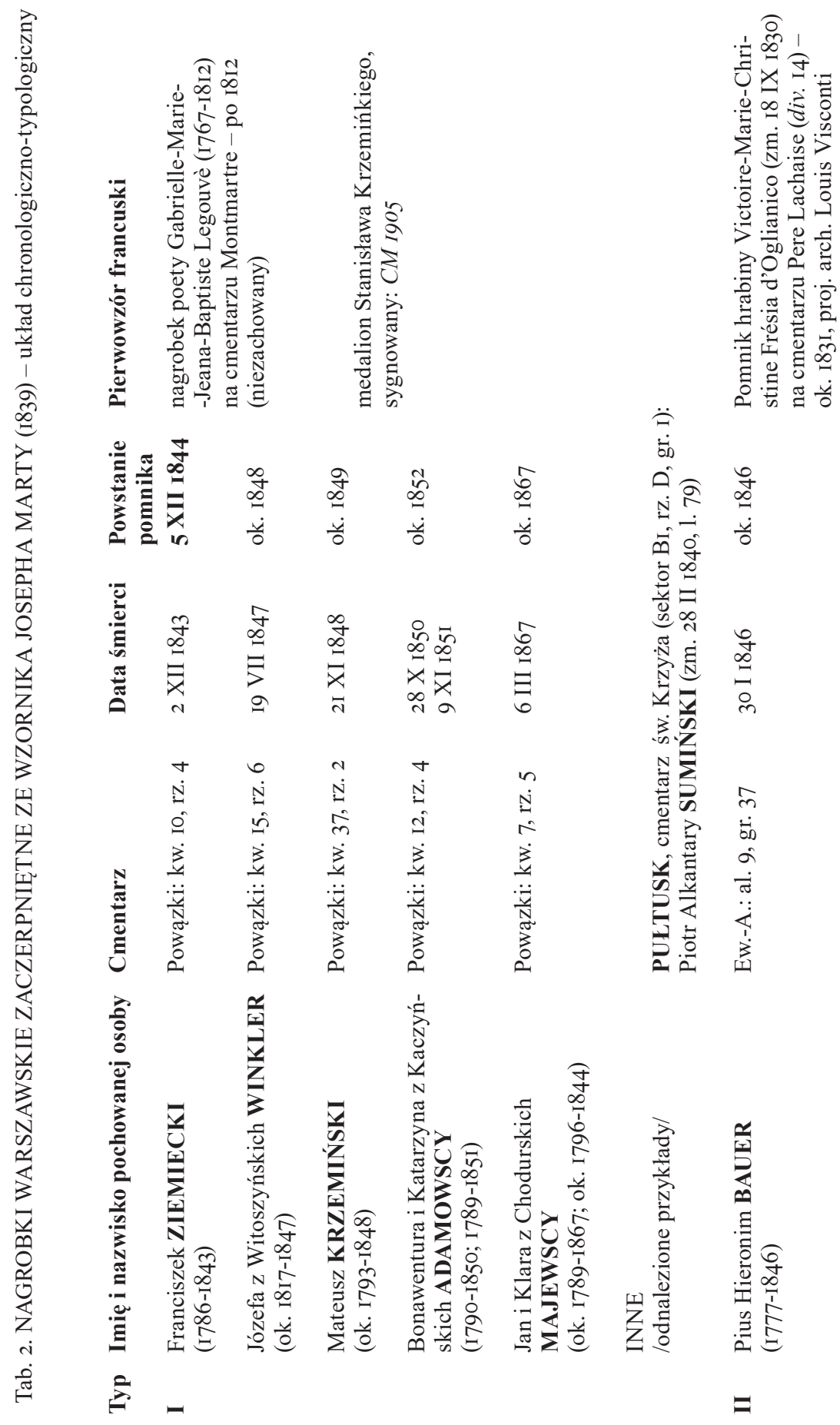




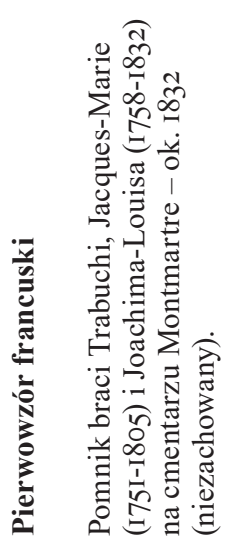

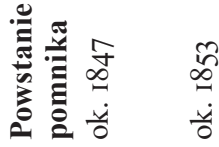

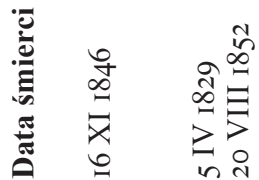

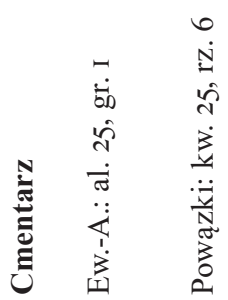

高

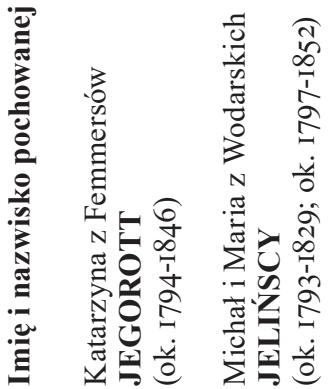

胥
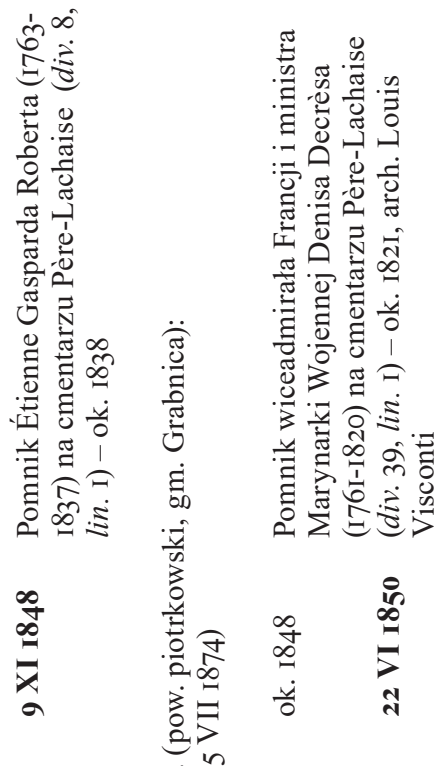

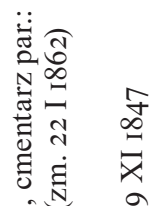

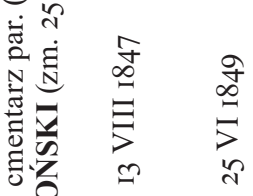

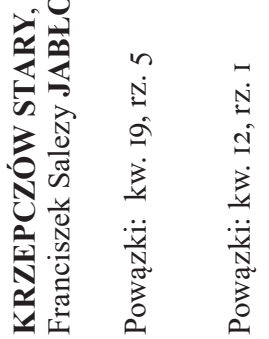

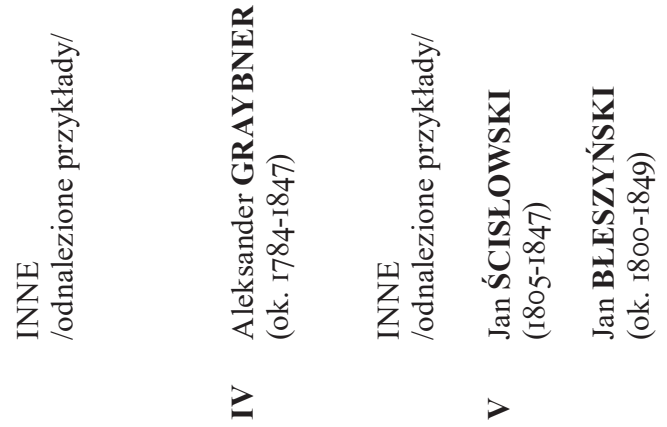


WYKORZYSTANIE PUBLIKACJI FRANCUSKICH PRZY REALIZACJI NAGROBKÓW... 307

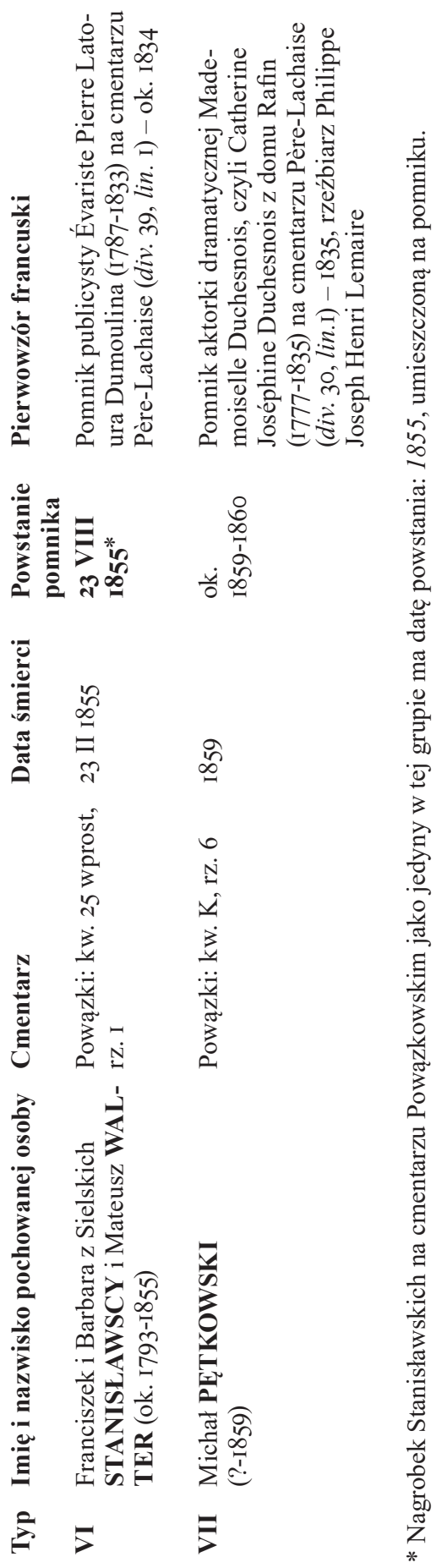




\section{The use of French templates during the execution of tombstones for the cemeteries of Warsaw from 1840 to 1860 . Joseph Marty template Summary}

The article in question is a continuity of the subject brought up in the magazine "Artifex Novus" published in October 20I7. Its first part referred to the tombstones created on the ground of works printed in Paris in I832 on the pages of two illustrated magazines whose authors were Ferdinando Quaglia and Louis-Marie Normand respectively. The other part was dedicated to the pattern book by Joseph Mart and the objects performed on its ground.

Collected pieces of information enable us to conclude that between I 840 and I 860 on the premises of the necropoleis of Warsaw a minimum of 20 tombstones, with the forms following those published in the above mentioned magazines, were raised. The vast majority of preserved examples, as many as I4, can be found on the premises of the Powązki Cemetery, another three were discovered at the Evangelical Augsburg Cemetery and two at the Evangelical Reformed Cemetery. Moreover, it has been stated that such tombstones happen to be funded on the premises of necropolies located outside the boundaries of the capital e.g. in Lublin, Pułtusk, Radom etc. Even though none of the tombstones was signed, it can be concluded the center of production and distribution was Warsaw and the stonework manufactures in operation in the city. Among others, attention was drawn to two manufactures: the one of Jan Ścisłowski (I805-I847) located at 6 Powązkowska Street, inherited and led by his two sons-in-law: Antoni Messing (I82I-I867) and Jan Bernard Sikorski (I832-I906), and the other belonging to the Mantzl family, Jan Józef senior - the father (I806-I875) and Józef Jan junior, - the son (I834-I906), the manufacture previously located at I9 Chłodna Street.

The tombstones funded and co-funded by relatives and friends were copings to graves of the wealthy, high officials, militaries, real estate and factory owners, entrepreneurs, merchants as well as craftsmen. The offer of the stonework manufactures in Warsaw reflected the taste of the elite, in the vast majority of Catholics of aristocratic descendance willing to show pro-French likeness and respect to the culture in question, having it as more sophisticated than the one dating back to the monarchy of Louis the XIV, and in particular, forming bonds with the empire of Napoleon Bonaparte the I.

Keywords: Powązki Cemetery in Warsaw, Evangelical Cemeteries in Warsaw, tombstone, Louis Marie Normand, Ferdinand Quaglia and Joseph Marty templates

[tł. Monika Kolenda]

\section{BIBLIOGRAFIA}

Źródła

Archiwum Archidiecezjalne Warszawskie (dalej: AAW), Akt urodzenia Franciszki Tekli Ziemieckiej, par. św. Jana Chrzciciela w Warszawie, I833, nr 85.

AAW, Akt urodzenia Zuzanny Katarzyny Winkler, par. św. Jana Chrzciciela w Warszawie, I835, nr 470 .

AAW, Akt urodzenia Wincenty Karoliny Winkler, par. św. Jana Chrzciciela w Warszawie, I837, nr 484 .

AAW, Akt małżéstwa Jana Antoniego Błeszyńskiego i Marianny Teresy Gierman, par. św. Jana Chrzciciela w Warszawie, I827, nr 217. 
AAW, Akt małżeństwa Karola Winklera i Józefy Łucji Witoszyńskiej, par. św. Jana Chrzciciela w Warszawie, I834, nr I48.

AAW, Akt małżeństwa Mateusza Krzemińskiego i Marianny Czyżewskiej, par. św. Aleksandra w Warszawie, I845, nr I6.

AAW, Akt zgonu Łukasza Krzemińskiego, par. św. Aleksandra w Warszawie, I829, nr 596. AAW, Akt zgonu Julii Błeszyńskiej, par. św. Jana Chrzciciela w Warszawie, I834, nr 366.

AAW, Akt zgonu Józefy Eucji Winkler, par. św. Jana Chrzciciela w Warszawie, I847, nr 390. AAW, Akt zgonu Jana Błeszyńskiego, par. św. Jana Chrzciciela w Warszawie, I849, nr 39I. AAW, Akt zgonu Marianny Błeszyńskiej, par. św. Jana Chrzciciela w Warszawie, I849, nr 585. Archiwum Państwowe m.st. Warszawy (dalej: APW), Akt urodzenia Agnieszki Stanisławskiej, par. św. Andrzeja w Warszawie, I829, nr 66.

APW, Akt matżeństwa Piusa Hieronima Bauera i Joanny Karoliny Heintz, Warszawa ASC Cyrkuł IV, I809, nr 25.

APW, Akt malżeństwa Mateusza Krzemińskiego i Barbary Katarzyny Wierzbickiej, Warszawa ASC Cyrkuł VII, I8I6, nr I25.

APW, Akt matżeństwa Aleksandra Józefa Graybnera i Franciszki Leonory Koprowskiej, Warszawa ASC Cyrkuł II, I8I7, nr 33.

APW, Akt matżeństwa Franciszka Ksawerego Ufniarskiego i Krystyny Fryderyki Nenneke, Warszawa ASC Cyrkuł VII, I82I, nr I5.

APW, Akt małżeństwa Franciszka Ziemieckiego i Marianny z Polakowskich Czyszkowskiej, Warszawa ASC Cyrkuł III, I822, nr II.

APW, Akt małżeństwa Michała Jelińskiego i Marianny Wodarskiej, Warszawa ASC Cyrkuł VII, I822, nr 8I.

APW, Akt małżeństwa Aleksandra Józefa Graybnera i Anieli Stanisławskiej, par. Nawiedzenia NMP w Warszawie, I826, nr 70.

APW, Akt małzeństwa Bernarda Ludwika Nasta i Joanny Eleonory Karoliny Bauer, par. ewang.-augsburska w Warszawie, I830, nr 58.

APW, Akt małżeństwa Karola Bichlera i Anny Marii Bauer, par. ewang.-augsburska w Warszawie, I836, nr 25.

APW, Akt matżeństwa Bonawentury Adamowskiego i Katarzyny Kaczyńskiej, par. św. Jana Chrzciciela w Warszawie, I837, nr I03.

APW, Akt matżeństwa Hieronima Piusa Bauera i Matyldy Amalii Nixdorf, par. ewang.-augsburska w Warszawie, I847, nr I6.

APW, Akt małzeństwa Jana Henryka Ludwika Bauera i Bronisławy Krzywickiej, par. ewang.-augsburska w Warszawie, I847, nr 62.

APW, Akt małżeństwa Franciszka Karola Brobka i Józefy Emilii Błeszyńskiej, par. św. Jana Chrzciciela w Warszawie, I847, nr I8I.

APW, Akt małżeństwa Ambrożego Majewskiego i Michaliny Jelińskiej, par. św. Krzyża w Warszawie, I848, nr I7.

APW, Akt matżéstwa Antoniego Messinga i Joanny Ścisłowskiej, par. Nawiedzenia NMP w Warszawie, I85I, nr 32.

APW, Akt małżeństwa Franciszki Tekli Ziemieckiej i Pawła Parola, par. św. Jana Chrzciciela w Warszawie, I852, nr II.

APW, Akt małżeństwa Ludwiki Aleksandry Ziemieckiej i Józefa Gepnera, par. św. Andrzeja w Warszawie, I854, nr 203. 
APW, Akt małżeństwa Jana Bernarda Sikorskiego i Teofili Ścisłowskiej, par. Nawiedzenia NMP w Warszawie, I860, nr I29.

APW, Akt zgonu Michała Jelińskiego, par. Nawiedzenia NMP w Warszawie, I829, nr 355.

APW, Akt zgonu Marianny Adamowskiej, par. św. Jana Chrzciciela w Warszawie, I832, nr 289. APW, Akt zgonu Bronisławy Błeszyńskiej, par. św. Jana Chrzciciela w Warszawie, I832, nr 516. APW, Akt zgonu Henryka Winklera, par. św. Andrzeja w Warszawie, I839, nr 92.

APW, Akt zgonu Franciszka Ziemieckiego, par. Nawiedzenia NMP w Warszawie, I843, nr 9I4. APW, Akt zgonu Klary Majewskiej, par. św. Aleksandra w Warszawie, I844, nr 85.

APW, Akt zgonu Józefa Winklera, par. św. Andrzeja w Warszawie, I845, nr Ioo.

APW, Akt zgonu Aleksandra Józefa Graybnera, par. św. Andrzeja w Warszawie, I847, nr 516. APW, Akt zgonu Jana Ścisłowskiego, par. Nawiedzenia NMP w Warszawie, I847, nr 840.

APW, Akt zgonu Mateusza Krzemińskiego, par. św. Andrzeja w Warszawie, I848, nr 653.

APW, Akt zgonu Marianny Ziemieckiej, par. Nawiedzenia NMP w Warszawie, I848, nr I377. APW, Akt zgonu Katarzyny Adamowskiej, par. św. Andrzeja w Warszawie, I85I, nr 578.

APW, Akt zgonu Mateusza Waltera, par. św. Andrzeja w Warszawie, I855, nr I2I.

APW, Akt zgonu Jana Majewskiego, par. św. Aleksandra w Warszawie, I867, nr 93.

APW, Akt zgonu Anieli Graybner, par. Przemienienia Pańskiego w Warszawie, I882, nr $20 \mathrm{I}$.

APW, Akt zgonu Stanisława Krzemińskiego, par. Najświętszego Zbawiciela w Warszawie, I9I2, nr 304.

Opracowania

Bochyński R.K., Plastyka nagrobkowa, w: Cmentarz rzymskokatolicki w Radomiu przy dawnym Trakcie Starokrakowskim obecnie ul. B. Limanowskiego, red. R. Brykowski, Radom I997, s. 3I-52.

Dębicki Z., Stanisław Krzemiński, „Kurier Warszawski”, I9I2, nr 33I dod. por., s. I-2.

Dubrowska M., Sołtan A., Powazkowskie medaliony i plakiety portretowe, Warszawa I992. Dymel P., Litwiński R., Cmentarze lubelskie, Lublin 2015.

Gmiter M., Kotowski B., Kucharska K., Laskowska B., Popek L., Cmentarz rzymskokatolicki przy ul. Lipowej w Lublinie, Lublin 1990.

Jouin H., La sculpture dans les cimetières de Paris, w: Nouvelles Archives de l'Art Français, t. I3, Paris I897.

Kowałko D., Cmentarze województwa zamoyskiego, Zamość I994.

„Kurier Warszawski”, I826, nr I63, s. 676, nr I76, s. 734.

„Kurier Warszawski”, I834, nr 47, s. 242.

„Kurier Warszawski”, I837, nr 60, s. 28I, nr I57, s. 769.

„Kurier Warszawski”, I839, nr 220, s. I06I-I062.

„Kurier Warszawski”, I840, nr 69, s. 325, nr 75, s. 353, nr 209, s. I002, nr 2I2, s. I0I7.

„Kurier Warszawski”, I843, nr 32I, s. I52I, nr 322, s. I529.

„Kurier Warszawski”, I844, nr I00, s. 469, nr 324, s. I533-I534.

„Kurier Warszawski”, I846, nr 3I, s. I4I, nr I03, s. 485, nr I07, s. 509.

„Kurier Warszawski”, I847, nr I9I, s. 9I9, nr I97, s. 947, nr 2I7, s. I042, nr 304, s. I449.

„Kurier Warszawski”, I848, nr 298, s. I437, nr 3I2, s. I50I, nr 32I, s. I54I.

„Kurier Warszawski”, I849, nr I62, s. 793-794, nr 254, s. I367.

„Kurier Warszawski”, I850, nr I59, s. 849, nr 279, s. I487, nr 287, s. I527.

„Kurier Warszawski”, I85I, nr I38, s. 7I8, nr 298, s. I595. 
„Kurier Warszawski”, I852, nr 220, s. II59.

„Kurier Warszawski”, I853, nr 7, s. 44.

„Kurier Warszawski”, I855, nr 53, s. 253, nr 220, s. II30, nr 263, s. I335.

„Kurier Warszawski”, I857, nr 55, s. 29I.

„Kurier Warszawski”, I865, nr 2I5, s. II33.

„Kurier Warszawski”, I867, nr 55, s. 329.

„Kurier Warszawski”, I872, nr I, s. 2.

„Kurier Warszawski”, I882, nr 235, s. 6, nr 243, s. 6, nr 289, s. 5.

„Kurier Warszawski”, I883, nr 30, s. 5, nr 45, s. 5.

„Kurier Warszawski”, I904, nr I75, s. 9.

Kwiatkowska M.I., Józef Jan Mantzel - warszawski rzeźbiarz i przedsiębiorca, „Rocznik Warszawski", 26/1996, s. 47-76.

Kwiatkowska M.I., Rzeźbiarze warszawscy XIX wieku, Warszawa 1995.

Marty J., Les principaux monuments funéraires du Père-Lachaise, de Montmarte, du Mont-Parnasse et autres cimetières de Paris, Paris I839.

Normand L.M., Monuments funéraires choisis dans les cimetières de Paris et des principales villes de France, Paris I832.

Omilanowska M., Uzupetnienie: Chetmica Duża, w: Katalog Zabytków Sztuki w Polsce, t. XI: Województwo bydgoskie, red. T. Chrzanowski, M. Kornecki, z. I8: Włocławek i okolice, opr. M. Paździor, W. Puget, T. Chrzanowski, M. Kornecki, Z. Rozanow, Warszawa I988, s. I9I-I92.

Quaglia F., Le Père Lachaise ou Recueil de dessins au trait et dans leurs justes proportions des principaux monuments de ce cimetière, Paris I832.

Procyk W., XIX-wieczny wzornik pomników nagrobnych. Próba określenia sposobów i zakresu wykorzystania wzorów na cmentarzu powązkowskim, w: Cemetery Art - Sztuka cmentarna - L'art de cimetière. Dokumenty sympozjum naukowego, 28-3o października I993 r., red. O. Czerner, I. Juszkiewicz, Wrocław I995, s. 277-286.

Rudkowski T.M., Cmentarz Świętokrzyski w Pułtusku, w: 200 lat cmentarza Świętego Krzyża w Puttusku, red. R. Lolo, Z. Morawski, Pułtusk 2004, s. 47-55.

Rudkowski T.M., Cmentarz Powazkowski w Warszawie. Panteon Polski, Wrocław 2014.

Szenic S., Cmentarz Powazkowski I790-I850. Zmarli i ich rodziny, t. I, Warszawa 1979.

Szwankowski E., Aleksander Józef Graybner (I786-1847), w: Polski Stownik Biograficzny, red. K. Lepszy, t. 8, Warszawa-Kraków-Wrocław I959, s. 557.

Wiraszka M., Wykorzystanie publikacji francuskich przy realizacji nagrobków na cmentarzach Warszawy w latach I840-I860. Wzorniki Normanda i Quaglia, „Artifex Novus”, 20I7, nr I, s. 44-59.

Wiraszka M., Antoni Messing - wspóttwórca pomnika Najświętszej Maryi Panny przed kościotem reformatów i serii wzorowanych na nim nagrobków wzniesionych na cmentarzach Warszawy, „Saeculum Christianum”, 23/ 20I6, s. 208-222.

Wiraszka M., Kaplice $i$ mauzolea na cmentarzach Warszawy w XIX i pierwszej połowie $X X$ wieku, t. I: Dzieła i ich twórcy, Warszawa 2017.

Wóycicki K.W., Cmentarz Powazkowski pod Warszawa, t. I i 2, Warszawa I855 i I856.

Zacharewicz Z., Wacław Sierakowski (I788-I839), w: Polski Słownik Biograficzny, red. H. Markiewicz, t. 37, Warszawa I996-I997, s. 315. 